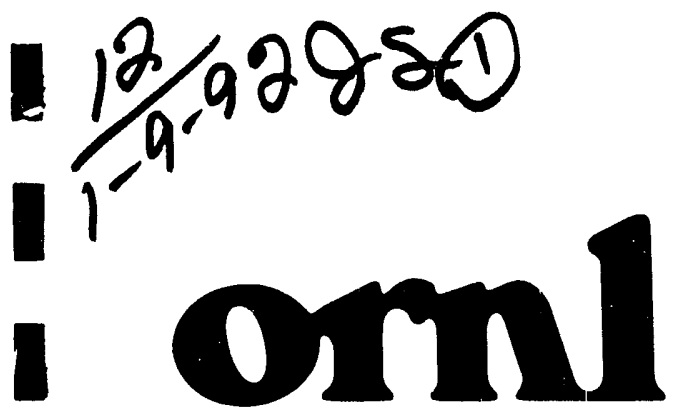

OAK RIDGE

NATIONAL

LABORATORY

MARTIN MARUETRA
Work Plan, Health and Safety Plan, and Quality Assurance Project Plan for Hazardous Waste Removal at the CTF K-1654B Underground Collection Tank

\author{
M. S. Panter \\ S. N. Burman \\ D. C. Landguth \\ M. S. Uziel
}


Health and Safety Research Division

\title{
Work Plan, Health and Safety Plan, and Quality Assurance Project Plan for Hazardous Waste Removal at the CTF K-1654B Underground Collection Tank
}

\author{
M. S. Panter \\ S. N. Burman \\ D. C. Landguth \\ M. S. Uziel
}

Date Issued-October 1991

\author{
Prepared by \\ Measurement Applications and Development Group \\ Prepared for \\ Martin Marietta Energy Systems, Inc. \\ Central Training Facility \\ under budget and reporting code GB \\ Oak Ridge National Laboratory \\ Oak Ridge, Tennessee 37831-6285 \\ managed by \\ MARTIN MARIETTA ENERGY SYSTEMS, INC. \\ for the \\ U.S. DEPARTMENT OF ENERGY \\ under contract DE-AC05-84OR21400
}

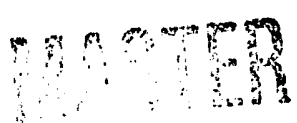




\section{Author Affiliations}

M. S. Panter is a University of Tennessee graduate student completing an internship in the Measurement Applications and Development (MAD) Group, Assessment Technology Section, Health and Safety Research Division (HASRD), Oak Ridge National Laboratory (ORNL). S. N. Burman, D. C. Landguth, and M. S. Uziel are members of the MAD Group at ORNL. 


\section{APPROVALS \\ Quality Assurance Project Plan for Hazardous Waste Removal at the \\ K-1654B Underground Collection Tank \\ (ORNL-6697)}

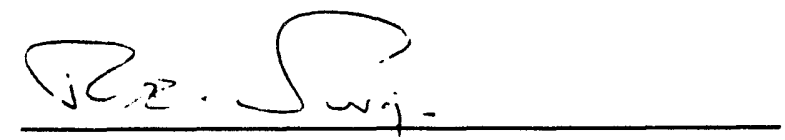

R. E. Swaja

ORNL/MAD Group Leader

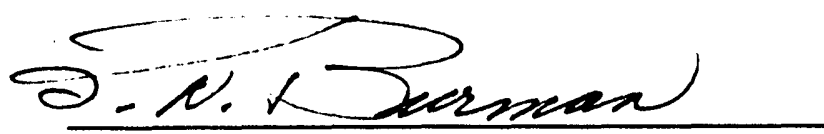

S. N. Burman

ORNL/MAD Site Project Manager

Y.A Ynatho

R. A. Mathis

ORNL/MAD Quality Assurance Officer

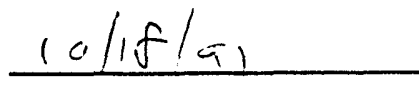

Date
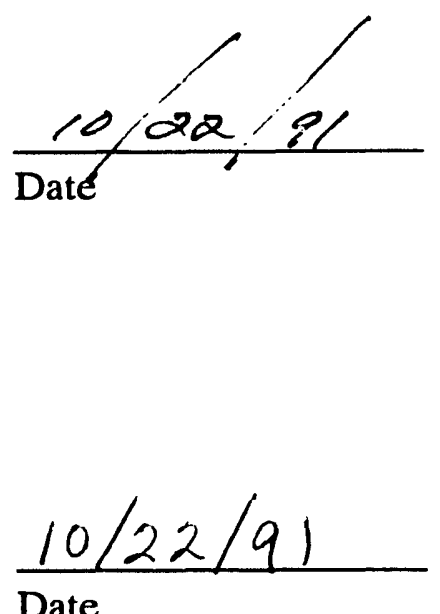

Date

$|0-2|-9$

Date

J. L. Davis

Central Training Facility Range Master 


\title{
APPROVALS
}

\author{
Health and Safety Plan \\ for Hazardous Waste Removal \\ at the \\ K-1654B Underground Collection Tank
}

(ORNL-6697)

$\frac{\text { t. n. me conf }}{\text { T. M. Mccoig }}$

$\frac{10-21-91}{\text { Date }}$

Central Training Facility Range Safety Officer

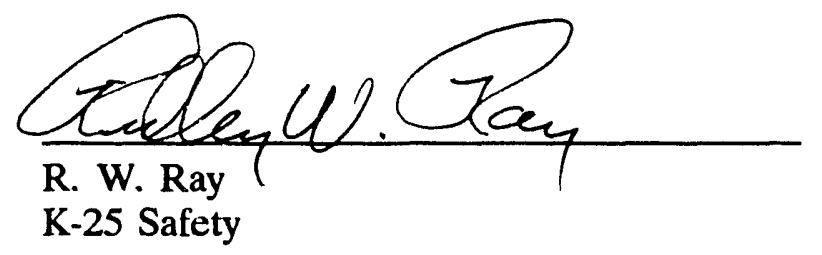

$10-22-91$

K-25 Safety

Date

A. W. Alwer

R. W. Oliver

K-25 Health Physics

$10-2 \mid-91$

Date

C. J. Satterwhite, Jr.

$\mathrm{K}-25$ Industrial Hygiene

$\frac{10-27-91}{\text { Date }}$

Q.2r. Sanbobur

A. W. Saulsbury

ORNL Hazardous Waste Operations and

Emergency Response Program Coordinator

$-10-21-91$

Date 


\section{CONTENTS}

QUALITY ASSURANCE PROJECT PLAN LOCATOR $\ldots \ldots \ldots \ldots \ldots \ldots \ldots$

FIGURES $\ldots \ldots \ldots \ldots \ldots \ldots \ldots \ldots \ldots \ldots \ldots \ldots \ldots \ldots \ldots \ldots \ldots \ldots$

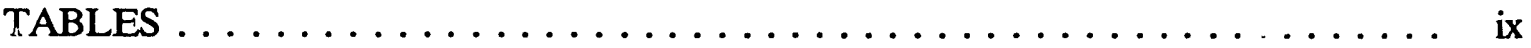

ACRONYMS $\ldots \ldots \ldots \ldots \ldots \ldots \ldots \ldots \ldots \ldots \ldots \ldots \ldots \ldots \ldots \ldots \ldots \ldots \ldots$

EXECUTIVE SUMMARY $\ldots \ldots \ldots \ldots \ldots \ldots \ldots \ldots \ldots \ldots \ldots \ldots \ldots \ldots$

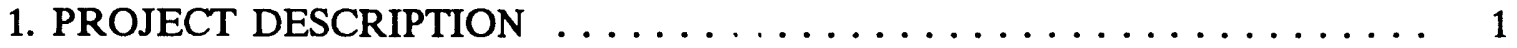

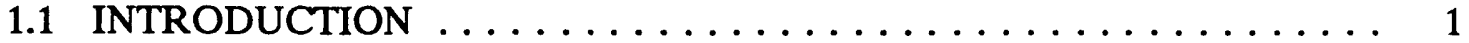

1.2 SCOPE AND OBJECTIVES .................... 1

2. PROJECT ORGANIZATION AND RESPONSIBILITIES $\ldots \ldots \ldots \ldots \ldots \ldots 4$

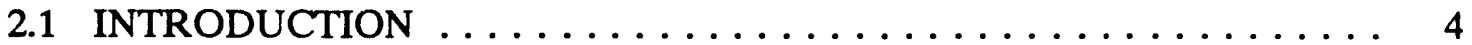

2.2 QUALITY ASSURANCE OFFICER $\ldots \ldots \ldots \ldots \ldots \ldots \ldots \ldots \ldots$

2.3 SITE PROJECT MANAGER $\ldots \ldots \ldots \ldots \ldots \ldots \ldots \ldots \ldots \ldots$

2.4 SITE HEALTH AND SAFETY OFFICER $\ldots \ldots \ldots \ldots \ldots \ldots \ldots \ldots$

2.5 FIELD PROJECT PERSONNEL $\ldots \ldots \ldots \ldots \ldots \ldots \ldots \ldots \ldots \ldots$

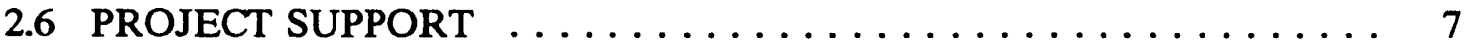

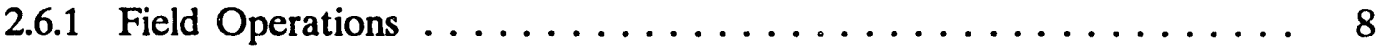

2.6.2 K-25 Industrial Hygiene Department $\ldots \ldots \ldots \ldots \ldots$

2.6.3 K-25 Health Physics Department ............... 8

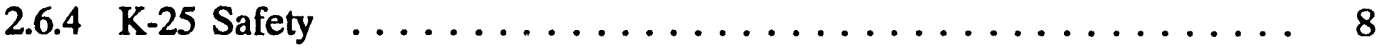

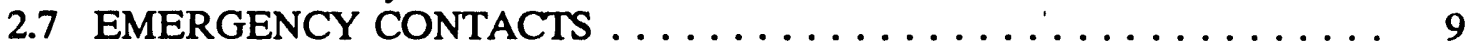

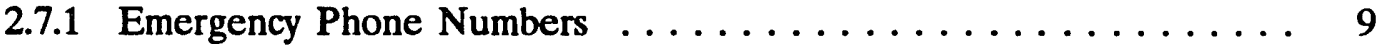

2.7.2 Emergency Preparedness . . . . . . . . . . . . . 11

3. QUALITY ASSURANCE OBJECTIVES FOR MEASUREMENT DATA $\ldots 14$

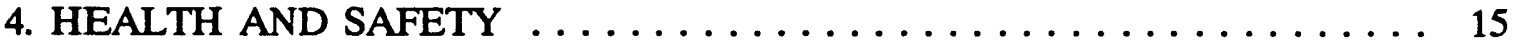

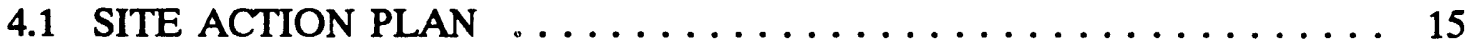

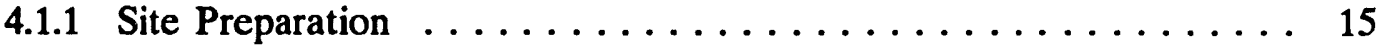

4.1 .2 Suspected Contaminants . . . . . . . . . . . . . . 17

4.1 .3 Contaminant Source $\ldots \ldots \ldots \ldots \ldots \ldots \ldots \ldots \ldots \ldots$

4.1.4 Tank Waste Removal . . . . . . . . . . . . . . . . . 17

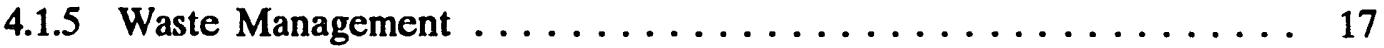

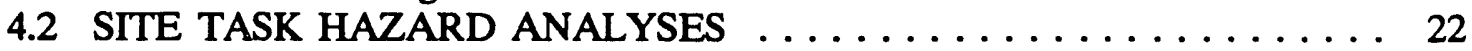

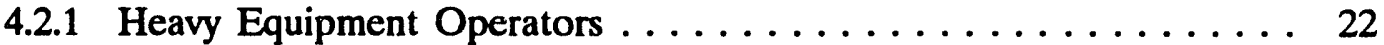

4.2 .2 Riggers and Laborers . . . . . . . . . . . . . . . . 22

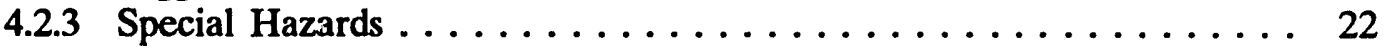

4.2.4 Determination of Work Area .................. 24

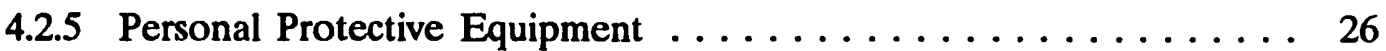

4.2.6 Standard Safe Work Practices . . . . . . . . . . . . . . 31 
4.3 PERSONNEL DECONTAMINATION PROCEDURES . . . . . . . . . 32

4.3.1 Level D Protection Decontamination . . . . . . . . . . . 32

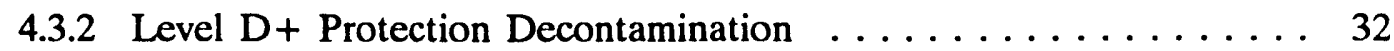

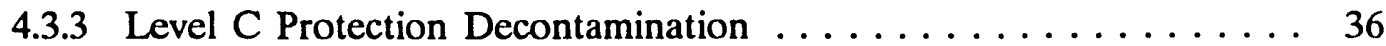

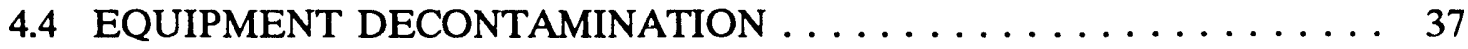

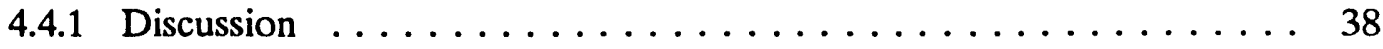

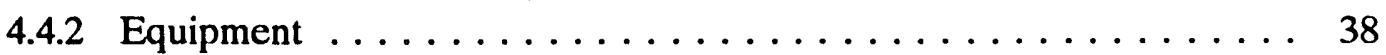

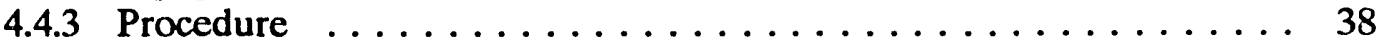

5. SAMPLING PROCEDURES, DOCUMENTATION AND CUSTODY . . . . . 42

6. CALIBRATION PROCEDURES $\ldots \ldots \ldots \ldots \ldots \ldots \ldots \ldots \ldots \ldots \ldots$

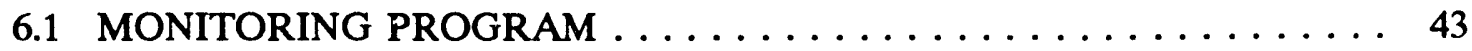

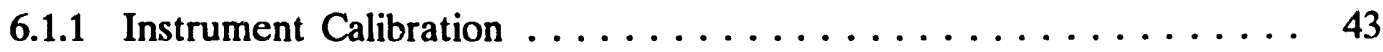

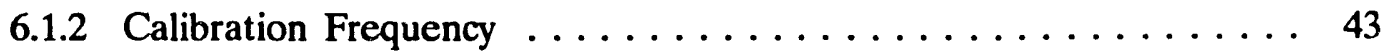

6.1.3 Background Readirgs . . . . . . . . . . . . . 43

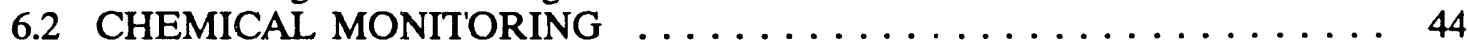

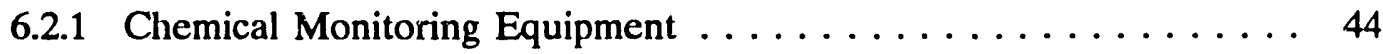

6.2 .2 Combustible Gas Indicator . . . . . . . . . . . . . 44

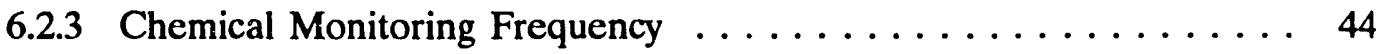

6.2.4 Chemical Monitoring Equipment Action Limits . . . . . . . . . 44

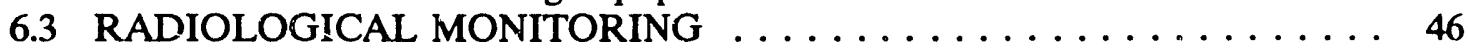

6.3.1 Radiological Monitoring Equipment . . . . . . . . . . . 46

6.3.2 NaI Scintillation Detector Source Check Procedures ... . . . . 47

6.3.3 Radiological Frequency and Action Limits . . . . . . . . . 47

7. ANALYTICAL PROCEDURES .................... 49

8. DATA MANAGEMENT PROCEDURES ................ 50

9. INTERNAL QUALITY CONTROL REQUIREMENTS . . . . . . . . . 51

10. PERFORMANCE AND SYSTEM AUDITS $\ldots \ldots \ldots \ldots \ldots \ldots \ldots \ldots$

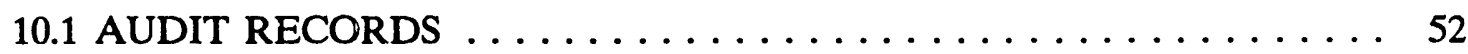

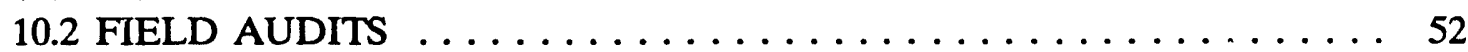

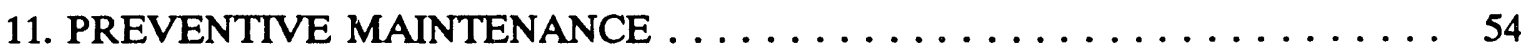

11.1 FIELD SAMPLING INSTRUMENTS $\ldots \ldots \ldots \ldots \ldots \ldots \ldots \ldots$

11.2 RADIOLOGICAL INSTRUMENTS $\ldots \ldots \ldots \ldots \ldots \ldots \ldots \ldots$

11.3 CHEMICAL DETECTION INSTRUMENTS $\ldots \ldots \ldots \ldots \ldots \ldots \ldots \ldots$

12. PROCEDURES USED TO ASSESS DATA PRECISION,

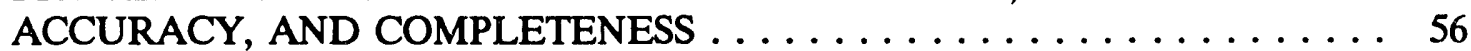

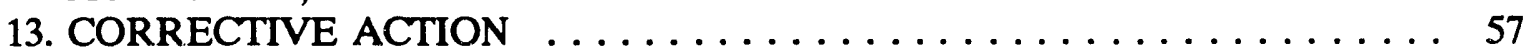

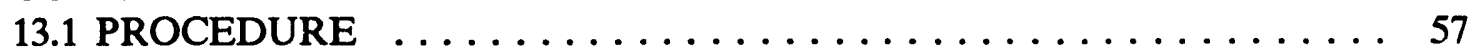

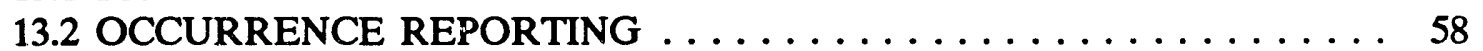

14. QUALITY ASSURANCE REPORTS TO MANAGEMENT . . . . . . . . 59

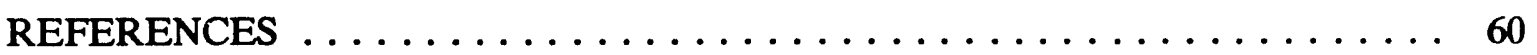

DISTRIBUTION $\ldots \ldots \ldots \ldots \ldots \ldots \ldots \ldots \ldots \ldots \ldots \ldots \ldots \ldots \ldots$ 


\section{QUALITY ASSURANCE PROJECT PLAN LOCATOR}

Essential Elements

1.0 Title page

2.0 Table of contents*

3.0 Project description

4.0 Project organization and responsibility

5.0 Quality assurance objectives for measurement data

6.0 Sampling procedures

(not applicable)

7.0 Sample custody

(not applicable)

8.0 Calibration procedures and frequency

9.0 Analytical procedures

(not applicable)

10.0 Data reduction, validation, and reporting

11.0 Internal quality control checks (not applicable)

12.0 Performance and system audits
Location

i

iii-iv

Sect. 1, pp. 1-3

Sect. 2, pp. 4-13

Sect. 3, p. 14

Sect. 5 , p. 42

Sect. 5 , p. 42

Sect. 6, pp. $43-48$

Sect. 7, p. 49

Sect. 8 , p. 50

Sect. 9, p. 51

Sect. 10 , pp. $52 \cdot-53$

\footnotetext{
*A list of all individuals receiving official copies of this Quality Assurance Project Plan is provided on page 61.
} 
13.0 Preventive maintenance

14.0 Procedures used to assess data precision, accuracy, and completeness

15.0 Corrective action

16.0 Quality assurance reports to management
Sect. 11, pp. 54-55

Sect. 12 , p. 56

Sect. 13 , pp. $57-58$

Sect. 14, p. 59 


\section{FIGURES}

1.1 Drawing of the K-1654B area at the Central Training Facility $\ldots \ldots \ldots 2$

4.1 "Drum Contents" label . . . . . . . . . . . . . . . . . . 19

4.2 Correct placement of labels on 55-gal, bung-top drum for liquids . . . . . . 20

4.3 Correct placement of labels on 55-gal, open-top drum for solids . . . . . . . 21

4.4 Diagram of site work zones showing exclusion zone, contamination reduction zone, and support zone ............ 25

4.5 Minimum decontamination requirements for

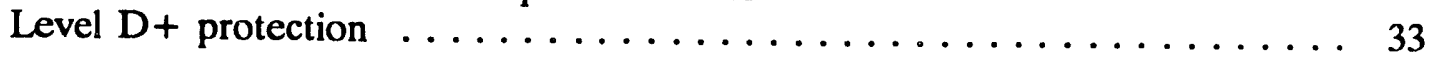

4.6 Minimum decontamination requirements for Level $\mathrm{C}$

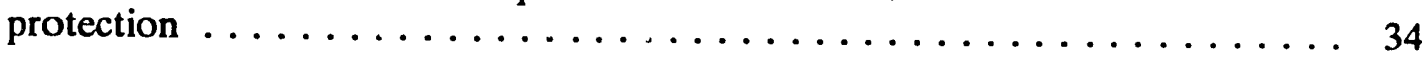

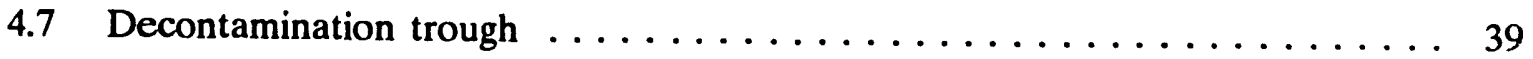

4.8 Photographs of decontamination trailer $\ldots \ldots \ldots \ldots \ldots \ldots \ldots$

6.1 Air quality monitoring record $\ldots \ldots \ldots \ldots \ldots \ldots \ldots \ldots \ldots$ 


\section{TABLES}

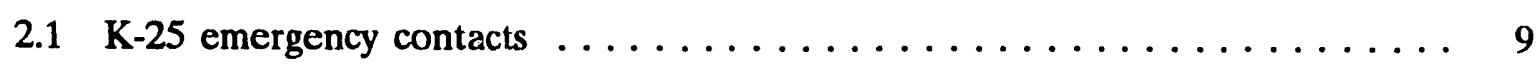

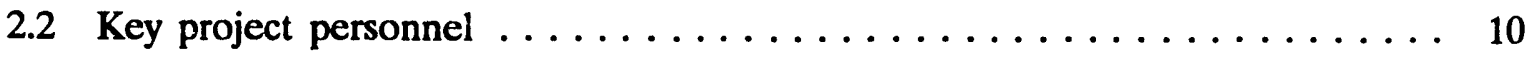

3.1 Summary of range, sensitivity, and precision criteria for field chemical and radiological monitoring instrumentation . . . . . . . . . 14

4.1 Characteristics of suspected contaminants at the K-1654B site . . . . . . 18

4.2 Protective equipment for on-site activities $\ldots \ldots \ldots \ldots \ldots \ldots \ldots$ 


\section{ACRONYMS}

ACGIH

ANSI

CAT

CGI

$\mathrm{CO}$

$\mathrm{CO}_{2}$

cpm

CRZ

$\mathrm{CS}_{2}$

CTF

DOE

DOT

dpm

EPA

eV

HASRD

HAZWOPER

HP

IH

LEL

MAD

$\mathrm{mg} / \mathrm{kg}$

$\mathrm{mg} / \mathrm{L}$

MSHA

$\mathrm{N}_{2}$

NIOSH

NIST

ORGDP

ORNL

ORS

OSHA

ppm

PS\&P

PSS

QA

QAPjP

QC

RCRA

SHSO

SPM

UCT
American Conference of Governmental Industrial

Hygienists

American National Standards Institute

Chemical Assessment Team

combustible gas indicator

carbon monoxide

carbon dioxide

counts per minute

contamination reduction zone

carbon disulfide

Central Training Facility

Department of Energy

Department of Transportation

disintegrations per minute

Environmental Protection Agency

electron vuit

Health and Safety Research Division

Hazardous Waste Operations and Emergengy Response health physics/health physicist

industrial hygiene/industrial hygienist

lower explosive limit

Measurement Applications and Development Group

milligrams per kilogram

milligrams per liter

Mine Safety and Health Administration

nitrogen

National Institute for Occupational Safety and Health

National Institute of Science and Technology

Oak Ridge Gaseous Diffusion Plant

Oak Ridge National Laboratory

occurrence reporting system

Occupational Safety and Health Administration

parts per million

Plant Support and Protection Division

plant shift superintendent

quality assurance

quality assurance project plan

quality control

Resource Conservation and Recovery Act

site health and safety officer

site project manager

underground collection tank 


\section{EXECUTIVE SUMMARY}

The Central Training Facility (CTF), located on Bear Creek Road approximately two miles south of the K-25 Site, is utilized for training security personnel at Martin Marietta Energy Systems, Inc., Oak Ridge, Tennessee. At the request of the CTF staff, this plan has been developed for the removal of the waste contents in the facility's 500-gal septic tank and associated distribution box. The septic tank and distribution box were historically located beneath the K-1654B trailer and adjacent to the K-1654A Indoor Firing Range. Recently, however, the K-1654B trailer was removed to accommodate the objectives of this work plan as well as future construction activities planned at CTF.

This 'Nolk $\mathrm{k}_{\mathrm{i}}$, health and safety plan, and quality assurance project plan was developed by the Heaith and Safety Research Division (HASRD) Measurement Applications and Development (MAD) group of Oak Ridge National Laboratory (ORNL) and will be implemented by ORNL/MAD. The major components of the plan include (1) a project description, which gives the scope and objectives of the ORNL/MAD investigation of the K$1654 \mathrm{~B}$ site and assigns responsibilities, including those associated with emergency situations occurring during the course of field operations; and (2) the K-1654B site activities health and safety plan, which describes general site hazards and particular hazards of specific tasks, including associated personnel protection requirements and mandatory safety procedures.

The purpose of this plan is to develop and assign responsibilities, establish personnel protestion requirements and mandatory safety procedures, and provide for contingencies that may arise while operations are being conducted by ORNL/MAD at the CTF K-1654B underground collection tank site. This document addresses requirements of 29 CFR 1910.120, Final Rule, with respect to aspects of health and safety applicable to an underground collection tank waste removal. 


\section{PROJECT DESCRIPTION}

\subsection{INTRODUCTION}

The Central Training Facility (CTF), located on Bear Creek Road approximately two miles south of the K-25 Site, is utilized for training security personnel at Martin Marietta Energy Systems, Inc., Oak Ridge, Tennessee. At the request of the CTF staff, this plan has been developed for the removal of the waste contents in the facility's 500-gal septic rank and associated distribution box. [Henceforth in this document, the septic tank and distribution box will be collectively referred to as the underground collection tank (UCT).] The K-1654B UCT was historically located beneath the $\mathrm{K}-1654 \mathrm{~B}$ trailer and adjacent to the $\mathrm{K}-1654 \mathrm{~A}$ Indoor Firing Range. Recently, however, the K-1654B trailer was removed to accommodate the objectives of this work plan as well as future construction activities planned at CTF. The $\mathrm{K}-1654 \mathrm{~B}$ UCT and its orientation adjacent to the K-1654A Indoor Firing Range is depicted in Fig. 1.1.

This work plan/health and safety plan was developed by the Health and Safety Research Division (HASRD) Measurement Applications and Development (MAD) group of Oak Ridge National Laboratory (ORNL), and project oversite as well as site health and safety will be implemented by ORNL/MAD. The major components of the plan include: (1) a project description, which gives the scope and objectives of the ORNL/MAD investigation of the $\mathrm{K}-1654 \mathrm{~B}$ site and assigns responsibilities, including those associated with emergency situations occurring during the course of field operations; and (2) the K-1654B site activities health and safety plan, which describes general site hazards and particular hazards of specific tasks, including associated personnel protection requirements and mandatory safety procedures.

The purpose of this plan is to develop and assign responsibilities, establish personnel protection requirements and mandatory safety procedures, and provide for contingencies that may arise while operations are being conducted by ORNL/MAD at the CTF K-1654B UCT site. This document addresses requirements of 29 CFR 1910.120, Final Rule, with respect to aspects of health and safety applicable to the UCT waste removal.

\subsection{SCOPE AND OBJECTIVES}

The objective of this plan is the removal of lead-containing waste withi i the K-1654B UCT. The potential for contamination exists as a result of K-1654A Indour Firing Range wash down activities and the subsequent direction of waste water into the K-1654B UCT. Based on activities conducted at the K-1654A Indoor Firing Range and results of sample analyses, the contaminant of concern is lead oxide from the discharge of firearms. Results from chemical analysis of samples collected at the K-1654B septic tank and distribution box showed total lead concentrations of 6300 and 8639 ppm, respectively (T. M. McCoig, Central Training Facility, personal communication to M. S. Panter, Health and Safety Research Division, Oak Ridge Natl. Lab., October 1991). This data bas not undergone a formal validation process. 

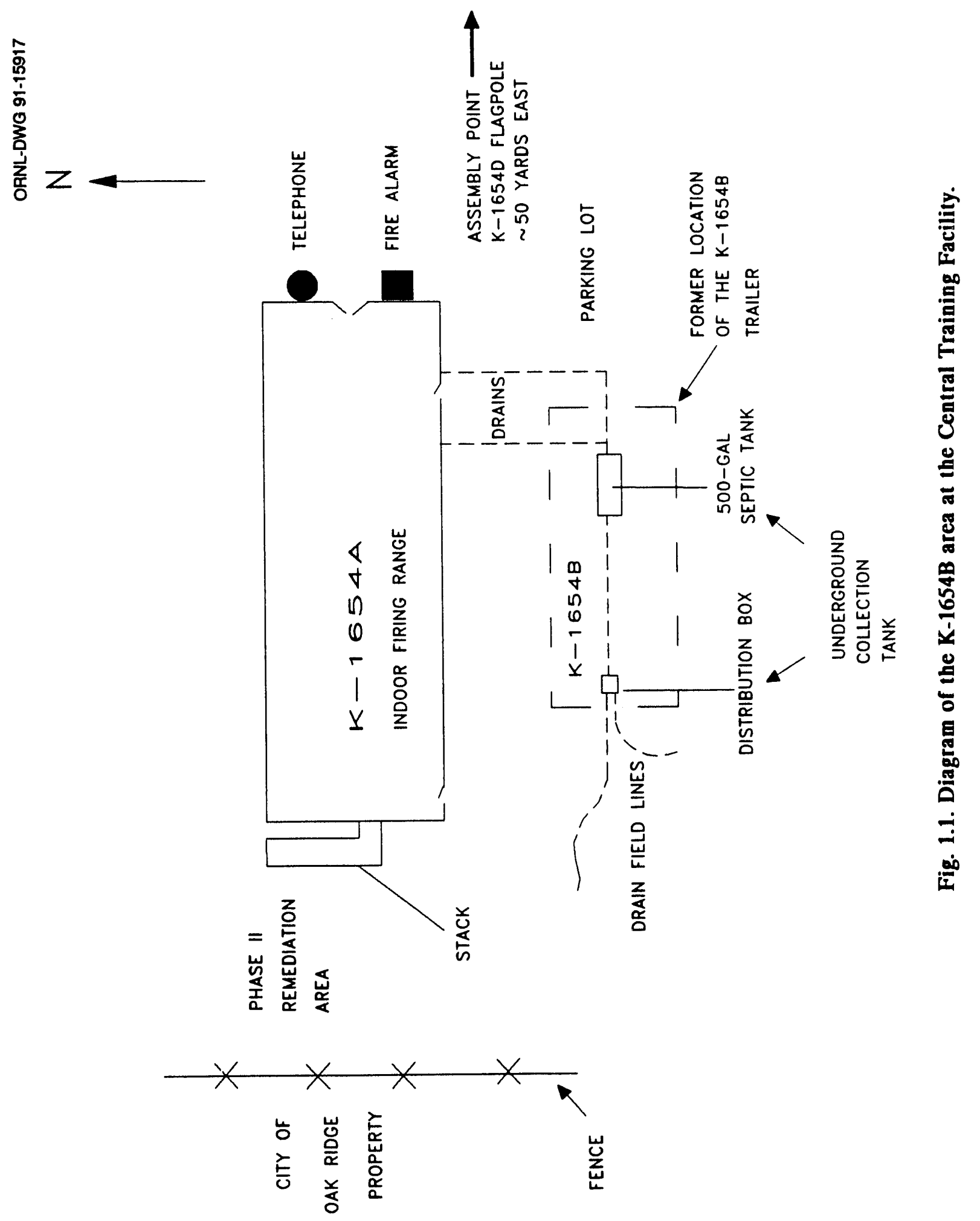
The waste removal will be conducted in the following phases: (1) surface radiological scanning, (2) exposing the tank, (3) removal of hazardous waste contents, and (4) recapping of the K-1654B UCT in preparation for future closure activities. 


\section{PROJECT ORGANIZATION AND RESPONSIBILITIES}

\subsection{NNTRODUCTION}

Key project personnel are identified in Sect. 2.7.1. Backups for key project personnel are listed where appropriate. The site project manager (SPM) or site health and safety officer (SHSO) may designate qualified alternates who are not identified in Sect. 2.7.1 to conduct their respective duties in the field, if warranted.

As of October 1, 1991, Energy Systems' General Employee Training is required of all personnel participating in work activities on the Oak Ridge Reservation. Because training records are not available to ORNL/MAD, verification of this training is the responsibility of the individual involved in K-1654B work activities and his/her supervision.

\subsection{QUALITY ASSURANCE OFFICER}

The ORNL/MAD quality assurance officer has stop-work authority and is responsible for the following items:

1. assisting the site project manager in resolving quality-related issues;

2. reviewing and approving quality assurance project plans (QAPjP);

3. reviewing project plans and procedures to ensure that all aspects of quality requirements have been adequately considered and addressed;

4. conducting quality surveillances, as necessary, for those aspects directly related to ORNL/MAD activities, to verify and document compliance with established procedures; and

5. following up corrective actions associated with audit or surveillance reports.

\subsection{SITE PROJECT MANAGER}

The SPM will oversee the CTF K-1654B UCT activities. He/she will be responsible for site accessibility, safety, and quality assurance (QA) and will delegate further responsibilities to other members of the ORNL/MAD team. The SPM has stop-work authority. Specific responsibilities of the SPM are listed below:

1. coordinating on-site operations, including logistics;

2. interfacing with plant and project personnel;

3. assisting the SHSO when necessary; 
4. participating in on-site characterization activities;

5. determining in-field procedural variances necessary to respond to site-specific conditions (see Sect. 13);

6. documenting and reporting unforeseen site-specific changes and corrective actions (see Sect. 13);

7. notifying all key project personnel of anticipated work scheduling; and

8. maintaining all site records and data; transferring all records and data to the ORNL/MAD group records files after job completion.

\section{SITE HEALTH AND SAFETY OFFICER}

The SHSO, sr a designated representative, with the support of the SPM, has primary responsibility for

1. Ensuring that personnel receive this work plan/health and safety plan and are aware of its provisions, are instructed in safe work practices, and are familiar with potential hazards and planned emergency procedures, prior to initiation of site activities.

2. Initiating the medical surveillance program for those who require it by previding a list of on-site personnel to the K-25 and ORNL Hazardous Waste Operations and Emergency Response (HAZWOPER) program coordinator. Requesting that individuals volunteer any medical information that would necessitate special consideration (e.g., allergies, diabetes, pregnancy); keeping confidential the medical information provided.

3. Confirming that all on-site personnel have received the training that qualifies them to work at a hazardous waste site.

4. Ensuring that all prospective site personnel sign and date the field logbook to verify that Items 1 through 3 were fulfilled.

5. Implementing health and safety plans, reporting to the SPM any deviations from anticipated conditions, and authorizing the cessation of work if necessary. If an unsafe condition or hazard arises during the investigation, ordering operations to cease, safeguarding personnel, and re-establishing safe working conditions after obtaining guidance from the industrial hygiene and/or health physics departments or their respective representatives.

6. Maintaining on-site copies of current training records for all on-site personnel in order to verify compliance with 29 CFR 1910.120 .

7. Ensuring that site workers have been properly trained and fitted for respiratory protection, as warranted. 
8. Establishing site work zones and required levels of protection. In addition, establishing personal decontamination stations and instructing personnel in their use.

9. Establishing and making available at the site an emergency action plan, with telephone numbers and appropriate radio communication information.

10. Identifying key plant personnel (and alternates) who are responsible for specific safetyrelated areas, such as health, plant safety, health physics, and industrial hygiene. In addition, establishing a liaison with the shift superintendent's organization to facilitate emergency response.

11. Minimizing the number of personnel and the amount of equipment in the exclusion zone that is consistent with safe site operations.

12. Field checking of the calibration of monitoring equipment that will be used that day and recording results in the field logbook.

13. Ensuring that all monitoring equipment is operating according to the manufacturer's specifications and instructions and providing maintenance, if warranted.

14. Prio: to commencing field work, ensuring that the penetration/excavation permit and any other necessary permits have been generated and that a signed copy is available on-site.

15. Ensuring that personnel stay clear of overhead work and temporarily suspended equipment.

16. Assisting personnel with the completion of report form(s), if needed. Ensuring that completed forms, either originals or copies, are returned to the ORNL/MAD SPM.

17. Providing continuous or periodic monitoring on-site for potential chemical contaminants while field operations are being conducted in the contamination reduction zone or the exclusion zone.

\section{FIELD PROJECT PERSONNEL}

Project personnel involved in on-site investigations and operations are responsible for

1. Taking all reasonable precautions to prevent injury to themselves and their fellow employees; being alert to potentially harmful situations.

2. Performing only those tasks that they believe they can do safely and immediately reporting any accidents and/or unsafe conditions to the SHSO and the SPM. 
3. Notifying the SHSO of any medical conditions (e.g., allergies, diabetes, pregnancy) that require special consideration. A medical department approval and/or a physician's recommendation may be required before an individual with a medical condition can be assigned a specific field task.

4. Avoiding contact with potentially contaminated substances (i.e., walking through puddles, pools, and mud) and avoiding placement of monitoring/sampling equipment on a potentially contaminated surface.

5. Preventing spillage. If a spillage occurs, containing the liquid if possible and notifying the SPM.

6. Avoiding splashing of contaminated materials.

7. Using all of their senses to alert them to potentially harmful situations.

8. Practicing good housekeeping by maintaining order, thereby reducing the likelihood of potentially harmful situations.

9. Being familiar with the physical characteristics of investigations, including

- awareness of the current surroundings at all times;

- accessibility to associates, equipment, and physical barriers;

- communications;

- hot zones (areas of known or suspected contamination);

- $\quad$ site access; and

- nearest site emergency resources.

10. Maintaining all wastes generated during the tank waste removal process for disposal according to Sect. 4.1.5 of this plan.

11. Reporting all injuries, no matter how minor, to the SHSO and SPM.

12. Abiding by a buddy system, so that each on-site worker is responsible for keeping track of his/her partner in the event of an incident.

\subsection{PROJECT SUPPORT}

The K-1654B UCT waste removal effort necessitates the participation of various Energy Systems organizations/disciplines. Individuals that represent their respective organization/discipline provide technical support to the project as needed. This technical support may include the review and comment of project documentation, consultation, and/or professional insight applied to project problems. Project support is a collaborative effort with responsibilities dictated by an individual's particular organization/discipline or project involvement. 


\subsubsection{Field Operations}

Field operations include those individuals participating in the actual waste removal at the $\mathrm{K}-1654 \mathrm{~B}$ site. The personnel involved in the day-to-day field work include ORNL/MAD SPM, SHSO, and field/site remediation personnel (subcontractors and student interns included). The tasks and responsibilities for these individuals are discussed in Sect. 2.2, 2.3, 2.4, and 2.5 of this document.

The ORNL/MAD group leader and QA officer contribute to the field operation effort; however, they do not participate in daily field activities. The ORNL/MAD group leader is the line manager for ORNL/MAD personnel, including ORNL/MAD subcontractors and students. The ORNL/MAD QA officer is responsible for the performance and documentation of QA surveillance, if needed. The QA officer also participates in the review and comment process for project work plans, health and safety plans, and the QAPjP.

\subsection{K-25 Industrial Hygiene Department}

The K-25 Industrial Hygiene Department shall be responsible for the oversight and approval of field investigative efforts related to industrial hygiene and the requirements of 29 CFR 1910.120. Within the industrial hygiene department, the K-25 HAZWOPER program coordinator shall approve all plans prior to the mobilization and commencement of field activities. The K-25 Industrial Hygiene Department and the K-25 HAZWOPER coordinator shall have stop-work authority regarding questions of industrial hygiene and may be consulted on these issues.

\subsubsection{K-25 Health Physics Department}

The K-25 Health Physics Department shall be responsible for the oversight and approval of field investigative efforts related to health physics. The health physics department shall approve all plans prior to the mobilization and commencement of field activities. In addition, the K-25 Health Physics Department shall have stop-work authority regarding questions of health physics and may be consulted on these issues.

\section{6 .4 K-25 Safety}

K-25 Safety shall be responsible for the oversight and approval of field investigative efforts related to safety and the requirements of 29 CFR 1910.120. In addition, K-25 Safety shall have stop-work authority regarding questions of safety and may be consulted on these issues. 


\section{EMERGENCY CONTACTS}

The plant shift superintendent (PSS) at the K-25 Site coordinates 24-h emergency response coverage from the Power and Shift Operation Department of the Plant Support and Protection Management (PS\&P) Division. The on-duty PSS, assisted by a well-trained plant emergency squad, is the overall coordinator responsible for directing the response to emergencies such as fires, major equipment failure, hazardous materials releases or spills, natural disasters, and sabotage.

\subsection{Emergency Phone Numbers}

Contact the Shift Superintendent first. The Superintendent is the trained emergency response director.

- Plant Phone: 911

- Cellular Phone: 574-3282

- $\quad$ Radio Number: Station \#9

Emergency groups and their telephone numbers are listed in Table 2.1. A cellular phone may be present in the field and available for use when workers are not in close proximity to a plant phone or radio.

Table 2.1. K-25 emergency contacts

\begin{tabular}{|c|c|}
\hline Contact & Telephone No. \\
\hline $\begin{array}{l}\text { Plant Shift Superintendent } \\
\text { (PSS) }\end{array}$ & $\begin{array}{l}911 \text { (plant phone) } \\
574-3282 \text { (cellular phone) } \\
\text { Station } 9 \text { (radio) }\end{array}$ \\
\hline Environmental Management & $574-8222$ \\
\hline Plant Protection (Security) & $574-8315$ \\
\hline Health Physics Department & $574-9620$ \\
\hline Health Physics Surveys & $574-0332$ \\
\hline Industrial Hygiene Department & $574-8567$ \\
\hline Medical & $574-8562$ \\
\hline Public Relations & $574-8093$ \\
\hline Safety (Operations) & $574-8568$ \\
\hline
\end{tabular}

${ }^{a}$ Contact the PSS first. The PSS is the trained emergency response director.

Key site personnel and titles or affiliations are listed in Table 2.2. 
Table 2.2. Key project personnel

\begin{tabular}{|c|c|c|}
\hline Responsibility & Name & Telephone \\
\hline ORNL/MAD Site Project Manager (SPM) & Steve Burman & $\begin{array}{l}576-7364 \\
\text { or on-site }\end{array}$ \\
\hline Alternate SPM & $\begin{array}{l}\text { David Landguth } \\
\text { Melissa Panter } \\
\text { Paul Abston } \\
\text { Glen Cofer }\end{array}$ & $\begin{array}{l}576-7363 \\
574-2777 \\
576-7362 \\
576-7362\end{array}$ \\
\hline $\begin{array}{l}\text { ORNL/MAD Site Health and Safety Officer } \\
\text { (SHSO) }\end{array}$ & Melissa Panter & $\begin{array}{l}574-2777 \\
\text { or on-site }\end{array}$ \\
\hline Alternate SHSOs & $\begin{array}{l}\text { Paul Abston } \\
\text { Glen Cofer } \\
\text { David Landguth } \\
\text { Steve Burman }\end{array}$ & $\begin{array}{l}576-7362 \\
576-7362 \\
576-7363 \\
576-7364\end{array}$ \\
\hline ORNL/MAD Group Leader & Dick Swaja & $576-5212$ \\
\hline ORNL/MAD Quality Assurance Officer & Richard Mathis & $574-5832$ \\
\hline $\begin{array}{l}\text { CTF Manager Protective Forces, Training and } \\
\text { Development }\end{array}$ & $\begin{array}{l}\text { Lee Barnes } \\
\text { Radio number }\end{array}$ & $\begin{array}{l}574-3220 \\
\text { EAGLE1 }\end{array}$ \\
\hline CTF Range Master & $\begin{array}{l}\text { J.L. Davis } \\
\text { Radio number }\end{array}$ & $\begin{array}{l}574-6069 \\
\text { EAGLE2 }\end{array}$ \\
\hline CTF Range Safety Officer & $\begin{array}{l}\text { Tom McCoig } \\
\text { Radio number }\end{array}$ & $\begin{array}{l}\text { 574-1537 } \\
\text { EAGLE12 }\end{array}$ \\
\hline $\begin{array}{l}\text { K-25 Industrial Hygiene Department } \\
\text { K-25 HAZWOPER Coordinator }\end{array}$ & $\begin{array}{l}\text { Charlie Satterwhite } \\
\text { Pager number }\end{array}$ & $\begin{array}{l}576-4544 \\
564-3509\end{array}$ \\
\hline ORNL HAZWOPER Coordinator & $\begin{array}{l}\text { Ann Saglsbury } \\
\text { Pager'n mbier }\end{array}$ & $\begin{array}{l}576-5064 \\
564-5805\end{array}$ \\
\hline K-25 Health Physics Department & $\begin{array}{l}\text { Bobby Oliver } \\
\text { Pager number }\end{array}$ & $\begin{array}{l}574-9086 \\
564-5517\end{array}$ \\
\hline Alternate K-25 Health Physics Department & $\begin{array}{l}\text { Steve Duboise } \\
\text { Pager number }\end{array}$ & $\begin{array}{l}576-3693 \\
564-2405\end{array}$ \\
\hline K-25 Safety & $\begin{array}{l}\text { Ridley Ray } \\
\text { Pager number }\end{array}$ & 574-8579 \\
\hline K-25 Fabrication and Maintenance & Jim Polston & $574-8627$ \\
\hline K-25 Fabrication and Maintenance & Dale Knox & $574-8636$ \\
\hline K-25 Environmental Management & Larry Ledford & $576-6961$ \\
\hline
\end{tabular}




\subsection{Emergency Preparedness}

Information in this section was obtained from the Construction Environmental, Safety, Health and Security Handbook (K/RA-101) and the K-25 Emergency Preparedness Department.

The on-duty PSS is the designated plant emergency director who is responsible for coordinating and responding to all emergency situations. The SHSO or the SPM will notify or assign someone to notify the PSS of an emergency situation as soon as possible.

\subsubsection{Reporting an emergency}

\section{Telephone}

- On a plant phone, dial 911. (Refer to Fig. 1.1 to locate the K-1654A Indoor Firing Range telephone.) On a cellular phone, dial 574-3282. When using a plant radio, call Station 9.

- Describe the type of emergency.

- Identify the location of the emergency.

- Identify yourself.

- In case of an injury, tell whether an amhulance is needed.

- $\quad$ Listen to and follow any instructions that are given.

2. Fire alarm pull boxes

Refer to Fig. 1.1 to locate the nearest fire alarm. Pulling a fire alarm box automatically transmits the location of the emergency to the fire department and the emergency control center. Remain at the alarm box, if possible, and supply any needed information to the responding emergency squad.

\section{Radio}

By calling Station 9, the shift superintendent will be alerted of the emergency.

- Confirm that it is an emergency call.

- Describe the emergency.

- Identify the location of the emergency.

- Identify yourself.

- Listen for any instructions. 


\subsubsection{Alarm signals}

\section{Evacuation alarms}

Evacuation alarms are denoted by a steady or continuous sounding from the plant public address (PA) system. The SHSO or SPM will designate the evacuation routes. Evacuate the site or area, proceed to the assembly point defined by the SHSO or SPM, and wait for further instructions.

\section{Radiation alarms}

Radiation alarms are denoted by rotating red beacon lights and a steady sound from a clarion horn. Evacuate the site or area, proceed to the assembly point defined by the SHSO or SPM, and wait for further instructions.

\section{Take cover alarms}

Take cover alarms are denoted by the intermittent or wailing siren sound from the plant PA system. Seek immediate protective cover in a strong sheltered part of a building. Evacuate mobile structures to a permanent building.

\section{Standard alerting tone}

The standard alerting tone is a high-low tone from the plant PA system. Listen carefully; an emergency announcement will follow.

\subsubsection{Evacuation procedures}

- Familiarize yourself with the evacuation routes that are designated by the SHSO or SPM.

- In the event of an evacuation, proceed to the K-1654D flagpole and wait for further instructions.

- The SHSO or SPM and crew will follow instructions given by the emergency response team upon its arrival.

\subsubsection{Medical}

Ordinarily K-25 personnel will report to the K-25 Health Services Center and ORNL personnel will report to the ORNL Health Services Center. However, in an emergency situation, the closest medical facility will be notified for emergency response.

\subsubsection{Important reminders}

- Know the telephone number of the plant shift superintendent, 574-3282 (cellular phone), 911 (plant phone), or Radio Station 9. 
- Know hew to summon an ambulance: Dial 911 from a plant phone or 574-3282 from a cellular phone and give the location. Wait for the arrival of first-aid personnel.

- Know the quickest way to summon the plant emergency squad: pull a fire alarm box and wait for the arrival of the emergency response team.

- Know the locations of fire alarms and emergency phones. 


\section{QUALITY ASSURANCE OBJECITVES FOR MEASUREMENT DA'A}

Quality assurance objectives for field measurement data only will be addressed in this document because sampling and analytical data collection are not a part of the K-1654 UCT waste removal project.

This section usually describes procedures for sample documentation, collection, packaging, and preservation that will be employed to ensure accuracy, precision, completeness, representativeness, and comparability in the collection of environmental samples and their subsequent analyses. Howe ${ }^{\circ} \mathrm{r}$, this plan will address only those aspects dealing with field measurements pertinent to health and safety for this particular waste removal project.

Sensitivity and precision criteria for field chemical and radiological monitoring instrumentation at the K-1654B UCT site are summarized in Table 3.1.

Table 3.1. Summary of range, sensitivity, and precision criteria for field chemical and radiological monitoring instrumentation

\begin{tabular}{|c|c|c|c|c|}
\hline Analytes & $\begin{array}{l}\text { Instrument, } \\
\text { detection } \\
\text { method }\end{array}$ & Range & Sensitivity & Precision \\
\hline Combustible gas & $\begin{array}{l}\text { CGI, catalytic } \\
\text { sensor }\end{array}$ & $\begin{array}{l}0-100 \% \text { of the } \\
\text { LEL based on } \\
\text { natural gas }\end{array}$ & $\begin{array}{l}1 \% \text {; based on } \\
2.5 \% \text { natural gas }\end{array}$ & $\mathrm{NA}^{b}$ \\
\hline Oxygen $\left(\mathrm{O}_{2}\right)$ & $\begin{array}{l}\text { CGI, } \\
\text { electrochemical } \\
\text { cell }\end{array}$ & $0-40 \% \mathrm{O}_{2}$ & $1 \% \mathrm{O}_{2}$ & NA \\
\hline $\begin{array}{l}\text { Hydrugen sulfide } \\
\left(\mathrm{H}_{2} \mathrm{~S}\right)\end{array}$ & $\begin{array}{l}\text { CGI, } \\
\text { electrochemical } \\
\text { cell }\end{array}$ & $0-100 \mathrm{ppm} \mathrm{H} \mathrm{H}_{2} \mathrm{~S}$ & $1 \mathrm{ppm} \mathrm{H} \mathrm{H}_{2} \mathrm{~S}$ & NA \\
\hline $\begin{array}{l}\text { Carbon } \\
\text { monoxide (CO) }\end{array}$ & $\begin{array}{l}\text { CGI, } \\
\text { electrochemical } \\
\text { cell }\end{array}$ & $0-300 \mathrm{ppm} \mathrm{CO}$ & $1 \mathrm{ppm} \mathrm{CO}$ & NA \\
\hline $\begin{array}{l}\text { Gamma } \\
\text { radiation }\end{array}$ & $\begin{array}{l}\text { NaI scintillator, } \\
\text { scintillation }\end{array}$ & $\begin{array}{l}-0-3 \mathrm{mR} / \mathrm{h} \\
\text { based on }{ }^{137} \mathrm{Cs}\end{array}$ & $\begin{array}{l}\text { Radiation levels } \\
\text { > background }\end{array}$ & $\pm 20 \%$ full scale \\
\hline
\end{tabular}

${ }^{a} \mathrm{LEL}=$ lower explosive limit.

${ }^{b} \mathrm{NA}=$ not applicable. 


\section{HEALTH AND SAFETY}

The health and safety aspects of this document conform to the Occupational Safety and Health Administration (OSHA) standard for Hazardous Waste Operations and Emergency Response (29 CFR 1910.120) as defined by the final rule of March 6, 1989. ORNL/MAD will designate a SPM, SHSO, and alternates who will implement, monitor, and enforce this plan. Inadequate health and safety precautions on the part of any on-site personnel or the belief that personnel are or may be exposed to an immediate health hazard shall be sufficient cause for the SHSO to suspend site work and require personnel to evacuate a potentially hazardous area.

Provisions of this plan apply to all on-site employees and visitors engaged in hazardous substance/waste management activities, including, but not limited to, initial site reconnaissance, preliminary field excavation, project operations, and demobilization.

This plan calls for the removal of the waste contents of the 500-gal UCT used as a waste water reservoir for wash down activities at the CTF indoor firing range. The proposed waste removal activities will be conducted by Martin Marietta Energy Systems, Inc., personnel according to the guidelines/requirements in this work plan.

The 500-gal septic tank was placed in service after the facility was constructed in 1978. In the original design of the indoor firing range, waste water from the wash down of the firing range floors was directed via a floor drain and approximately $31 \mathrm{ft}$ of piping into the septic tank located beneath K-1654B. The waste water was then directed to a distribution box and dispersed via drain field lines into the soil at the south and southwest perimeters of K-1654B. In October of 1989, the floor sweepings were analyzed using the EP Toxicity procedures and found to contain lead in concentrations as high as $610 \mathrm{ppm}$ in the leachate, exceeding the EP Toxicity 0 ; ppm for lead as outlined in 40 CFR 261.24. Consequently, sediments from the septic tank and its associated distribution box were analyzed and shown to contain 6300 and $8639 \mathrm{ppm}$ of total lead, respectively. Based on this information, the septic tank was taken out of service in November 1989.

\subsection{SITE ACTION PLAN}

\section{1.i Site Preparation}

Before the site work activities are implemented, the site will be thoroughly checked and monitored for any possible ignition sources. In addition, No Smoking signs and other warnings will be posted in plain view.

A pre-entry health and safety briefing will be conducted prior to the commencement of field operations so that field personnel may become familiar with potential hazards and required field procedures. All persons involved in the UCT waste removal procedure (including subcontractors and representatives from the K-25 Site, such as industrial hygiene department, health physics department, safety, security, engineering, and the physical plant) 
will be required to attend the pre-entry briefing. A "make-up" pre-entry briefing will be conducted for any individuals not in attendance who later require admission to the contamination reduction zone or the exclusion zone. At the pre-entry briefing, the SHSO will explain the UCT waste removal procedures and safety requirements. All personnel involved in the UCT waste removal project, and others who may require access to the exclusion or contamination reduction zone, will be required to provide copies of certificates indicating completion of required training. This documentation should be presented to the SHSO at the time of the pre-entry briefing.

The SHSO will call attention to any potential health and safety factors that might influence the project. Emergency procedures will be addressed at this time, as will any questions pertaining to health and safety aspects of the tank waste removal project. Upon completion of the health and safety briefing, each person attending the meeting will be required to sign and date the field logbook indicating that he/she has received a pre-entry health and safety briefing and understands all aspects of the tank waste removal project. All involved individuals will then receive a copy of this plan and in so doing agree to conduct operations in accordance with this plan. "Tailgate" meetings may be called periodically during field activities to apprise on-site personnel of potential health and safety concerns that arise due to unplanned field conditions.

Unusual site features and requirements of the CTF K-1654B site necessitate the following considerations:

- Section (e)(3)(i) of 29 CFR 1910.120 (March 9, 1989) requires that all workers on the site in a full-time capacity receive a minimum of $40 \mathrm{~h}$ of off-site health and safety training in addition to a minimum of 3 days $(24 \mathrm{~h})$ of actual field experience under direct supervision. Copies of certificates documenting successful completion of required training should be presented to the SHSO at the pre-entry briefing.

- All personnel working on the site must have attended the pre-entry health and safety briefing, and documentation of the training must be entered in the field logbook before access to the contamination reduction zone and/or exclusion zone may be granted. All personnel will also be on the existing Energy Systems radiological dosimetry program.

- All individuals entering the exclusion zone or contamination reduction zone must be on a medical monitoring program for hazardous work, as specified in 29 CFR 1910.120 (March 9, 1989). The K-25 Industrial Hygiene Department and both the ORNL and the K-25 HAZWOPER coordinator will be notified of those individuals requiring medical surveillance.

- In the event that a confined space entry is required, those individuals entering, serving as attendants, monitoring, or supervising a confined space entry must have completed the Energy Systems' approved confined space entry training and provided the SHSO with the appropriate certification. (NOTE: The K-25 Industrial Hygiene Department has declared the K-1654B UCT site free of a confined space entry designation when work activities proceed under normal conditions, external to the tank.) 
- As of October 1, 1991, Energy Systems' General Employee Training is required of all personnel participating in work activities on the Oak Ridge Reservation. Because training records are not available to ORNL/MAD, verification of this training is the responsibility of the individual involved in $\mathrm{K}-1654 \mathrm{~B}$ work activities and his/her supervision.

\subsubsection{Suspected Contaminants}

Table 4.1 lists possible site contaminants and associated hazards, in addition to physical descriptions and pertinent chemical characteristics. Chemicals are listed based on information from historic site data and conversations with individuals familiar with the operations carried out within the building and surrounding area. Chemicals used in the site decontamination activities also appear on the list.

\subsubsection{Contaminant Source}

The CTF UCT was used as a reservoir for waste water generated during wash down activities conducted in the K-1654A Indoor Firing Range. This health and safety plan will be used during the removal of hazardous waste located inside the K-1654B UCT.

\subsubsection{Tank Waste Removal}

After surface radiological scanning, the first step in the waste removal process will be excavation of the superficial soil covering the UCT lid. The lid will then be removed to allow assessment of waste contents and placement of the pumping equipment. The liquid contents along with any solid residuals will be pumped out first. In the event that solid residuals do not lend themselves to pumping, scooping will be initiated to reduce the possibility and/or duration of confined space entry. If necessary, liquid rinsing will be introduced in order to place the residual waste in solution, thereby rendering it susceptible to pumping. If residual waste still remains, manual removal will involve entrance into the tank such that all requirements for confined entry must be adhered to including training and monitoring.

Once the K-1654B UCT has been declared devoid of waste contents, the lid will be replaced. Any further remediation or site cleanup will be the responsibility of CTF.

\subsubsection{Waste Management}

The liquid waste generated from removal activities will be drummed in Department of Transportation (DOT) 17E type 55-gal drums. Solid waste such as sediment extracted from the tank will be drummed in specified DOT 17C 55-gal drums. Prior to using a drum, a "Drum Contents" label (Fig. 4.1) with all information filled out will be affixed. No drum is to be used until this label is displayed on it. Proper placement of labels on 55-gal burig-top and open-top drums is illustrated in Figs. 4.2 and 4.3, respectively. Closed, secured drums will be transported to an approved RCRA storage facility at the K-25 Site for proper management. 
Table 4.1. Characteristics of suspected contaminants at the K-1654B site

\begin{tabular}{|c|c|c|c|c|}
\hline Contaminant & $\begin{array}{l}\text { TLV'-TWA }{ }^{b} \text { or } \\
\text { PEL'-TWA }\end{array}$ & $\begin{array}{l}\text { TLV-STEL }{ }^{d} \text { or } \\
\text { PEL-STEL }\end{array}$ & $\begin{array}{l}\text { Target organs/ } \\
\text { miscellaneous } \\
\text { information }\end{array}$ & $\begin{array}{c}\text { Chemical and physical } \\
\text { properties }\end{array}$ \\
\hline $\begin{array}{l}\text { Alconox (from } \\
\text { equipment } \\
\text { decontamination) }\end{array}$ & $\begin{array}{l}\text { TLV-TWA = } \\
10 \mathrm{mg} / \mathrm{m}^{3} \text { (dust) }\end{array}$ & $N A^{f}$ & $\begin{array}{l}\text { Inhalation of powder } \\
\text { may cause local } \\
\text { irritation to mucous } \\
\text { membranes }\end{array}$ & $\begin{array}{l}\text { White powder, } \\
\text { odorless, } \\
\text { nonflammable }\end{array}$ \\
\hline $\begin{array}{l}\text { Isopropyl alcohol } \\
\text { (from equipment } \\
\text { decontamination) }\end{array}$ & $\begin{array}{l}\text { TLV-TWA= } \\
400 \mathrm{ppm}\end{array}$ & $\begin{array}{l}\text { TLV-STEL= } \\
500 \text { ppm; } \\
\text { PEL-STEL= } \\
500 \text { ppm }\end{array}$ & $\begin{array}{l}\text { Mild irritant to eyes, } \\
\text { nos :, throat, } \\
\text { res ji. dtory system }\end{array}$ & $\begin{array}{l}\text { Colorless liquid with } \\
\text { an odor of rubbing } \\
\text { alcohol, FP: } 53^{\circ} \mathrm{F} \text {, } \\
\text { LFL: } 2.0 \% \text {, UFL: } \\
\text { 12.0\%, LEL: } 2.0 \% \text {, } \\
\text { UEL: } 12.0 \%\end{array}$ \\
\hline $\begin{array}{l}\text { Lead (as } \mathrm{Pb} \text { ) and } \\
\text { lead oxide }\end{array}$ & $\begin{array}{l}\text { TLV-TWA= } \\
0.15 \mathrm{mg} / \mathrm{m}^{3} \\
\text { PEL-TWA= } \\
0.05 \mathrm{mg} / \mathrm{m}^{3}\end{array}$ & $\begin{array}{l}\text { STEL }=\text { NA } \\
\text { IDLH }{ }^{g}=700 \\
\mathrm{mg} / \mathrm{m}^{3}\end{array}$ & $\begin{array}{l}\text { GI tract, CNS, kidneys, } \\
\text { blood, gingival tissues }\end{array}$ & $\begin{array}{l}\text { Light grey powder; } \\
\text { Sol:insoluble; FP:NA, } \\
\text { UFL/LFL:NA; } \\
\text { Incompatible with } \\
\text { strong oxidizers, } \\
\text { hydrogen peroxide, } \\
\text { acids }\end{array}$ \\
\hline
\end{tabular}

${ }^{a} \mathrm{TLV}=$ threshold limit value.

${ }^{b}$ TWA $=$ time-weighted average.

${ }^{c} \mathrm{PEL}=$ permissible exposure limit.

${ }^{d}$ STEL $=$ short-term exposure limit.

${ }^{\mathrm{e}} \mathrm{FP}=$ flash point, LFL = lower flammability limit, UFL = upper flammability limit, LEL = lower explosive limit, UEL = upper explosive limit.

$f_{\mathrm{NA}}=$ not available.

8IDLH = immediately dangerous to life and health.

Source: American Conference of Governmental Industrial Hygienists, 1991-1992 Threshold Limi Values for Chemical Substances and Physical Agents and Biological Exposure Indices, ISBN:0-936712-92-9, Cincinnati, OH, 1991 and National Institute for Occupational Safety and Health, NIOSH Pocket Guide to Chemical Hazards, DHHS(NIOSH) Publication No. 90-117, Cincinnati, OH, June 1990. 


\section{DRUM CONTENTS \\ (Waste type)}

DISPOSAL REQUEST No.\# (то ве suppliad)

CONTACT T. M. Mccoig 4 -1537

BUILDING (sampling Site)

DATE FILLED

(Date Drum is Filled)

Fig. 4.1. 'Drum Contents' label. 
ORNL-DWG 91-15918

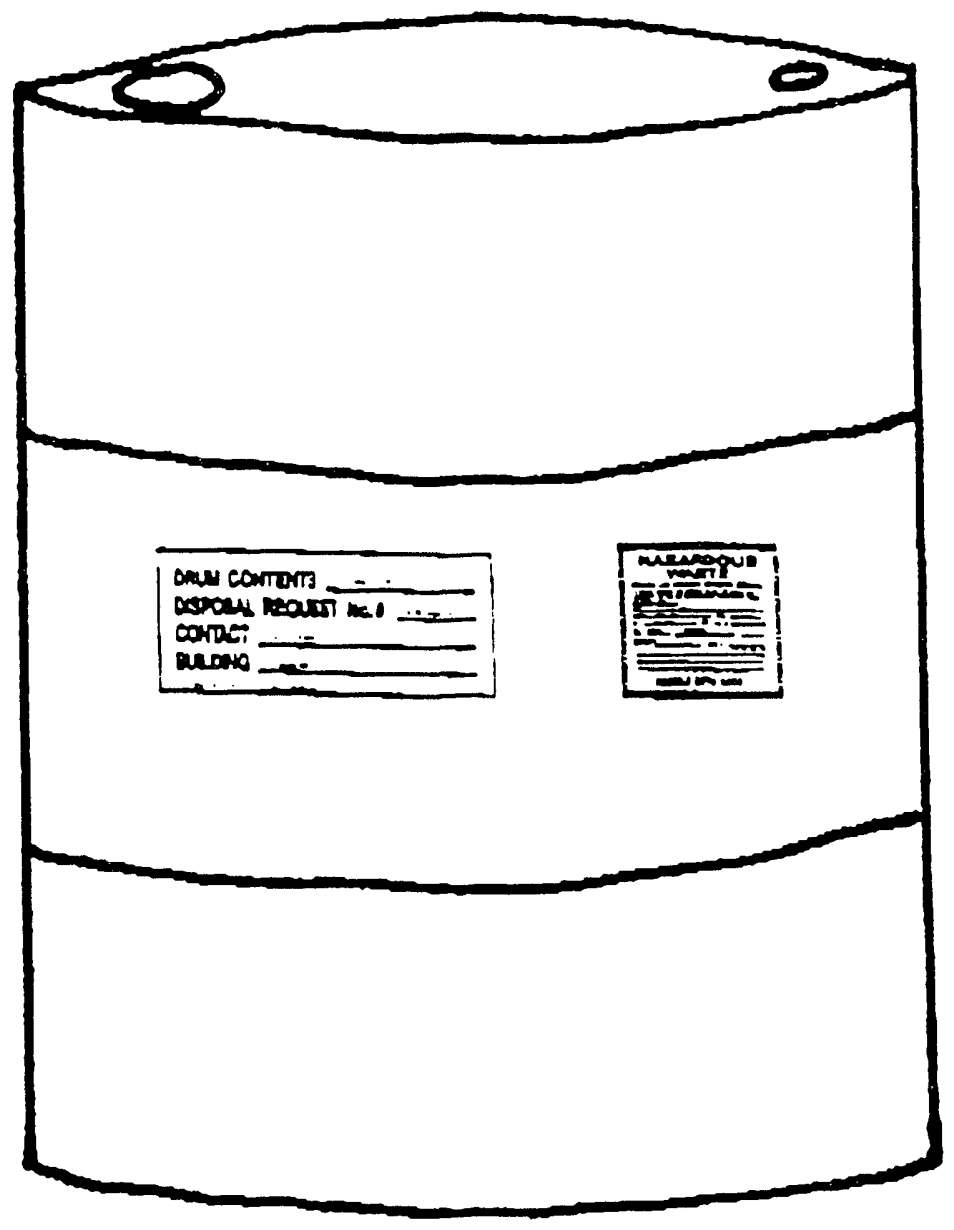

Fig. 4.2. Correct placement of labels on 55-gal, bung-top drum for liquids. 
ORNL-DWG 91-15919

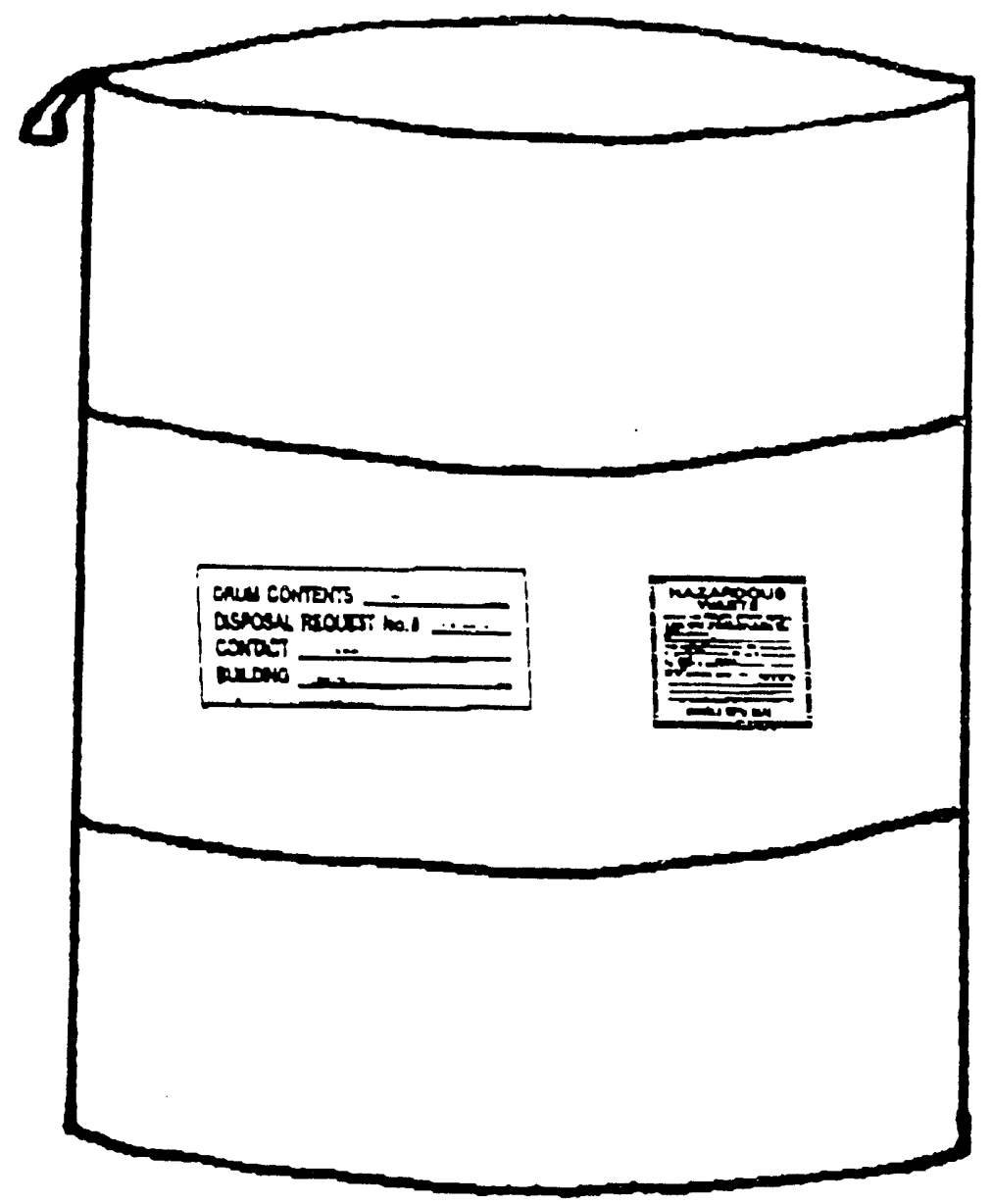

Fig. 4.3. Correct placement of labels on 55-gal, open-top drum for solids. 
All decontamination fluids and compactible waste will be drummed in appropriate waste receptacles and properly labeled as specified by the K-25 Waste Disposal Coordinator. The decontamination fluids will be drummed as flammable and nonflammable fluids. All drums will be stored on pallets in the 90-day accumulation area established on-site.

\subsection{SITE TASK HAZARD ANALYSES}

The site task hazard analysis is intended to identify potential health and safety hazards that site personnel may encounter. In addition, necessary personal protective equipment will be identified by the SHSO, the SPM, the health physics technician or the on-site industrial hygiene department representative and, depending on field conditions, may be upgraded or downgraded. Personnel decontamination requirements, including donning and doffing procedures for various levels of protection, are outlined in subsequent sections of this document.

\subsubsection{Heavy Equipment Operators}

Personnel operating heavy equipment will use Level D personal protective equipment, although changing field conditions may require an upgrade by the SHSO. Safety precautions must be observed when operating around the site. People working around construction equipment should be aware that operators have blind spots in their field of vision. A grounding cable will be attached to the piece of equipment to prevent the generation of static electricity. The hazards associated with the operation of heavy equipment are generally injury to personnel, equipment damage, or property damage.

\subsubsection{Riggers and Laborers}

In the event that removal of residual sediment becomes necessary, the riggers and laborers may be responsible for the manual removal of chemical hazards within the confines of the K1654B UCT. These individuals must stay away from chokers and slings associated with heavy equipment used to remove the lid. Their duties may also involve confined-space entry following appropriate monitoring and approval by the SHSO or the industrial hygiene department representative. Any individuals who might be required to make a confined space entry will have the appropriate Energy Systems' approved training. Level D+ personal protective equipment will be utilized unless changing field conditions warrant an upgrade, which will be determined by the SHSO, the SPM, and/or the inciustrial hygiene department representative.

\subsubsection{Special Hazards}

In addition to the physical, chemical, and toxicological hazards of lead waste, other types of potential hazards are present on site. All site personnel may potentially be exposed to the hazards outlined below. 


\subsubsection{Heat stress and cold stress}

Activities being conducted at the CTF may be physically demanding during much of the investigative efforts, possibly compounded by moderate to heavy work loads, ambient air temperatures, relative humidity, and the use of protective clothing and equipment.

Acclimatization will help personnel function in both hot and cold environments. Acclimatization is a physical and psychological adjustment that workers experience during the first one or two weeks of work in hot or cold environmental conditions. Especially during this period, workers should concentrate on maintaining a balanced diet, consuming plenty of fluids throughout the day, wearing the proper clothing, and remaining aware of telltale signs of heat-related stress (e.g., headaches, dizziness, high body temperature, and/or increased heart rate) or cold-related stress (e.g., headaches, numbness in digits or extremities, dizziness, low body temperature, and/or decreased heart rate). It is imperative that the SHSO be informed of the condition if a worker experiences these signs.

All activities that take place at the investigative site require the use of a "buddy" system. As field activities continue, all personnel should be aware of their buddy's condition and of signs of heat- or cold-related stress. The SHSO will institute a work/rest regimen to combat heat- or cold-related disorders, according to his/her best professional judgement and (ACGIH).

\subsubsection{Biological Stress}

Field conditions may present a variety of biological stresses, and it is the responsibility of investigative personnel to inform the SHSO of health conditions they have that may be affected by on-site biological stresses. Examples of these stresses may include, but are not limited to, bee stings, ticks, snakes, poison ivy, or asthmatic conditions that may be affected

\subsubsection{Illumination}

Normal operating conditions at the CTF site will involve conducting field activities during daylight hours. A minimum of $5 \mathrm{ft}-\mathrm{c}$ will be required to conduct field activities, however, actual field measurements of illumination will not be made. A conservative guideline may be that field work will commence $15 \mathrm{~min}$ after sunrise and conclude $15 \mathrm{~min}$ prior to sunset. Adherence to the minimum $5 \mathrm{ft}-\mathrm{c}$ requirement will depend on the SHSO's best professional
judgement. 


\subsubsection{Dust}

Based upon previous experience associated with unearthing activities, dust generation will be minimal. A general rule of thumb is that a visible cloud of dust will constitute an action limit. An engineering control, such as wetting with deionized water, may be employed to control dust. The water is usually sprayed as a fine mist from a garden sprayer. In the unlikely event that engineering controls are unsuccessful, K-25 Industrial Hygiene will be summoned to assess the situation and provide guidance.

\subsubsection{Ergonomics}

Potential hazards related to the interaction of personnel with their working environment may be present at this site. Primary ergonomic hazards may include lifting heavy loads, equipment vibrations, body positioning, and physical obstacles associated with lifting tasks. Personnel should always position themselves properly and lift from the legs. Personnel should seek assistance in lifting loads that are too heavy for one person. Back strain, the most common ergonomic hazard in the field, may be easily avoided, provided that on-site workers always ask for assistance when they need it.

Laborers may encounter vibration when operating equipment. If operators experience tingling of the digits, the SHSO will apply his/her best professional judgement to institute appropriate work/rest regimens. If any ergonomic symptoms are encountered in the field, the SHSO must be notified immediately.

\subsection{Determination of Work Area}

The following sections will be used in the determination of work zones for the K-1654B UCT site. Zones will be cordoned off with flagging and appropriate placards.

\subsubsection{Zone 1: exclusion zone}

The exclusion zone is the zone where the potential of coming into contact with contamination is greatest (see Fig. 4.4). All personnel entering the exclusion zone will have the prescribed level of protective equipment, training, and medical surveillance as determined by the SHSO. An entry and exit check point will be visually defined at the periphery of the exclusion zone to regulate the flow of personnel and equipment into and out of the zone.

Prohibited items or conduct in the exclusion zone include the following:

- beards and long sideburns (if respiratory protection is required);

- eating, smoking, drinking, or the chewing of anything;

- personal articles (e.g., watches and rings);

- failure to inform the SPM or SHSO of any illness that could affect safety or cause healthrelated complications;

- removal of respiratory protective equipment under Level C or higher protection;

- access to the exclusion zone by any individual not having the required health and safety training in accordance with OSHA regulations 29 CFR 1910.120(e)1 and (e)2; 
ORNL -DWG 91-15923

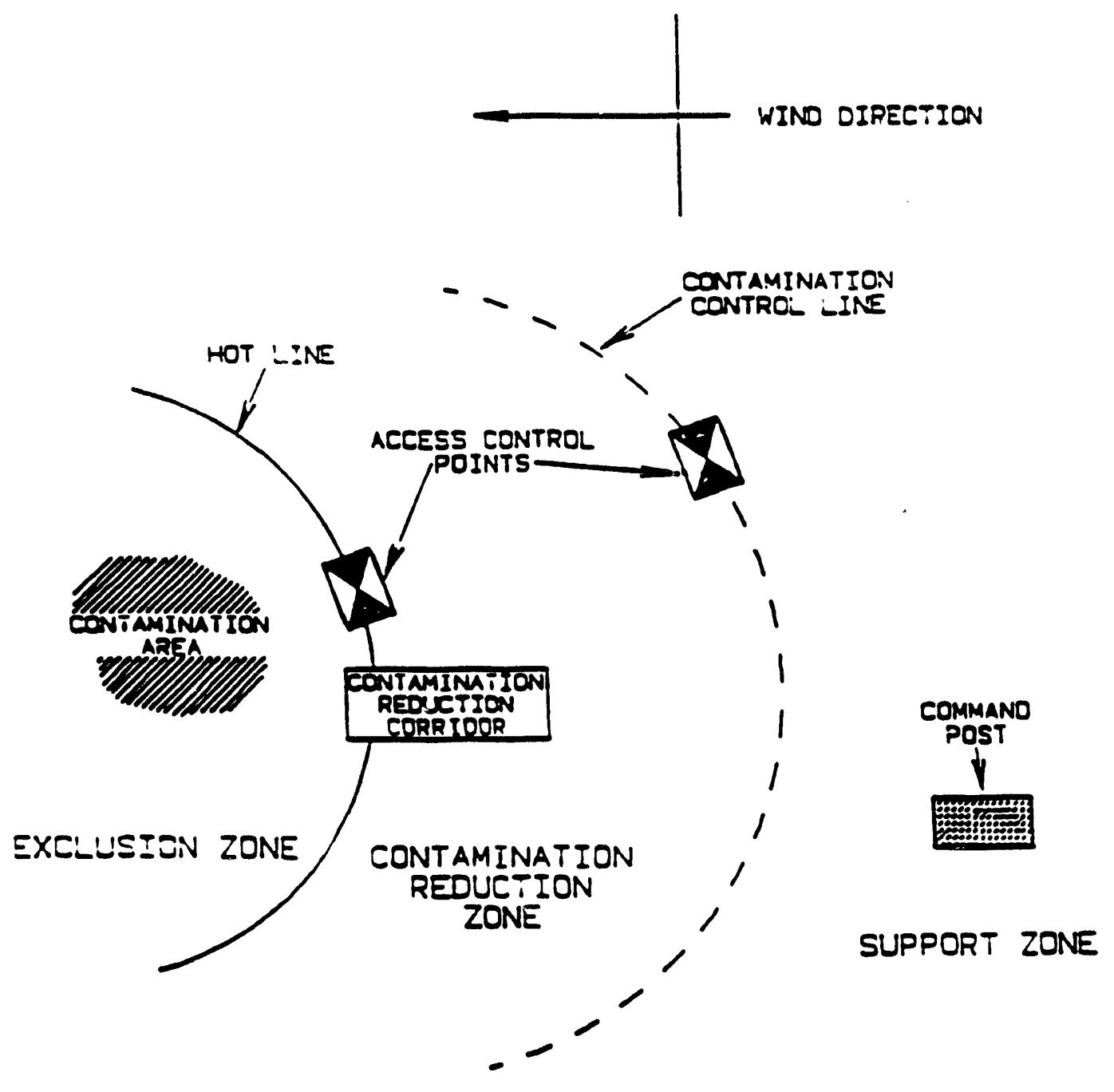

Fig. 4.4. Diagram of site work zones showing exclusion zone, contamination reduction zone, and support zone. 
- any individual that does not possess the appropriate training documeniation to gain entrance to the site;

- any conduct or item thought to be potentially dangerous to the well-being of on-site personnel;

- application of insect spray or cosmetics, since interaction of these substances with other chemicals is possible;

- any person who has not attended a pre-entry briefing.

\subsubsection{Zone 2: contamination reduction zone}

As shown in Fig. 4.4, a contamination reduction zone is established outside the exclusion zone. This zone provides a transition between the exclusion zone (potentially contaminated zone) and the support zone (clean zone). It serves as a buffer to further reduce the possibility of the support zone from becoming contaminated. It provides additional assurance that the physical transfer of contaminating substances on personnel, equipment, or in the air is limited through a combination of decontamination, distance between exclusion and support zones, air dilution, zone restrictions, and work functions. At the boundary between the exclusion and contamination reduction zones, decontamination stations for the sole purpose of personnel decontamination will be established. Personnel decontamination stations will be constructed as detailed in Sect. 4.3. Equipment decontamination will be accomplished as described in Sect. 4.4 of this document.

\subsubsection{Zone 3: support zone}

The support zone (clean zone) is shown in Fig. 4.4. The support zone will be marked by flags and placards and protected against contamination from the work site.

The support zone primarily functions as:

- the entry area for personnel, material, and equipment;

- the exit area for decontaminated personnel, materials, and equipment;

- a storage area for clean safety and work equipment; and

- an area for rest breaks, the consumption of food and beverage and all other activities.

\subsubsection{Personal Protective Equipment}

All personal protective equipment for the different site activities, tasks, and work zones is based upon the potential site-specific contaminants and may involve conservative additions to personnel protection by ORNL/MAD, K-25 Industrial Hygiene Department, or K-25 Health Physics Department. All personal protective equipment for the exclusion zone is based upon OSHA requirements and conservative additions to personncl protection by ORNL/MAD. Guidelines for personal protective equipment for site activities, tasks, and work zones is to be specified by the SHSO using Table 4.2 and the list below: 
Table 4.2 Protective equipment for on-site activities

\begin{tabular}{lcl}
\hline Activity & Level & Protective equipmentab $^{a, b}$ \\
\hline Heavy equipment operators & D & $\begin{array}{l}\text { Hard hat, safety glasses, } \\
\text { hard-toed footwear, field } \\
\text { work clothes, face shield, } \\
\text { gloves, hearing protection } \\
\text { (if necessary) }\end{array}$ \\
$\begin{array}{l}\text { Excavating and removal } \\
\text { activities }\end{array}$ & D+ & $\begin{array}{l}\text { Same as above pliss } \\
\text { chemical-resistant } \\
\text { polyethylene-lined Tyvek } \\
\text { clothing, chemical- } \\
\text { resistant disposable gloves, } \\
\text { nitrile or butyl rubber } \\
\text { outer boots }\end{array}$ \\
\hline
\end{tabular}

${ }^{a}$ Chemical-resistant gloves, outer boots, and Tyvek clothing may be worn by personnel to reduce the danger of potential splashing and to maintain persona! hygiene. The information in this table should not be construed to mean the requirement of all personnel to conform to this practice. All site personnel and visitors must contact the site project manager or site health and safety officer to confirm actual personnel protection requirements prior to entering an investigation site.

${ }^{b}$ Full-faced face shield mounted on hard hats with safety glasses will be worn during the equipment decontamination process.

1. Level $\mathrm{C}$ protective equipment
a. full face respirator with air purifying cartridge (GMC-H filter) capable of filtering out lead oxides and radionuclides
b. hooded chemical-resistant clothing (Tyvek) with all seams and openings taped
c. gloves (chemical-resistant inside and outside)
d. safety-toed footwear
e. hard hats

2. Level $\mathrm{D}+$ protective equipment
a. chemical-resistant (polyethylene-lined) Tyvek clothing
b. chemical-resistant disposable gloves
c. safety-toed footwear
d. hard hats
e. safety glasses

3. Level D pro. sctive equipment
a. coveralls/field clothes
b. gloves 
s. safety-toed footwear

d. safety glasses

e. hard hats

The outer protective garment should be a chemical-resistant woven material (Tyvek or equivalent). This material has the ability to form a protertive barrier against detrimental chemicals for a specific period of time based on the chemical in question. Each chemical has its own permeating ability, and the resistance of the protective clothing will vary with each chemical. For some chemicals, the risk of chemical permeation increases when an outer protective garment becomes damp from soil or water contact. Based upon the nature of the waste removal process, a field investigator whose outer protective suit becomes wet should replace the wet garment as soon as possible with a new Tyvek suit.

All respiratory protective equipment will be approved by the National Institute for Occupational Safety and Health (NIOSH) and the Mine Safety and Health Administration (MSHA). All personnel required to use respiratory protection shall have had an up-to-date quantitative respirator fit test and wear only the model and size respirators approved by the quantitative fit test. In addition, site personnel will abide by a single-use respirator ivlicy. Once the seal of the respirator has been broken (i.e., for lunch and other breaks), a new respirator will be donned in place of the previous respirator.

\subsubsection{Protective clothing donning procedure}

The purpose of the protective clothing donning procedure is to ensure that on-site personnel are instructed in the proper donning of protective clothing. Failure to adhere to this procedure may result in the protective clothing being ineffective against a potential contaminant. The following donning procedure is given as a guide and may be altered by the SHSO if procedural improvements can be made and are warranted in the field. In addition, some articles of protective clothing/equipment detailed in the following may not be necessary for the particular site task. Personnel should consult the SHSO for the appropriate protective equipment combination.

1. Inspect clothing and respiratory equipment before donning.

2. Adjust hard hat to fit.

3. Place legs in suit while standing or sitting and pull safety boots through. Gather up at the waist and place arms in sleeves. Pull upper portion of the suit over the shoulders, and zip the suit closed.

4. Place boot covers over the safety boots if required. Tuck pant leg into boot cover. Tape the boot covers to the leg of the suit, providing a seal, and tab the tape to permit removal.

5. Dos the respirator after performing the initial qualitative checks of the respirator's integrity. All personnel who may be required to wear respirators should familiarize themselves with Sect. 4.2.5.3 (Respiratory protection). 
6. Perform the necessary qualitative respirator fit test under the direct supervision of the SHSO.

7. Draw hood up around the respirator. Seal exposed facial areas between the suit and the respirator with tape.

8. Don both pairs of chemical-resistant gloves; insert sleeve of work clothes inside inner glove and seal with tape. Insert sleeve of suit inside outer glove and seal to suit with tape. A tab should be provided on the tape to ease removal of gloves during decontamination procedures.

\subsubsection{Protective clowiing doffing procedure}

The purpose of the protective clothing doffing procedure is to ensure that all on-site personnel are instructed in the removal of protective equipment. Failure to adhere to this procedure may result in unnecessary exposure to a potential on-site contaminant. The following doffing procedure is given as a guide and may be altered by the SHSO or the health physics department representative if procedural improvements can be made and are warranted in the field. In addition, some protective equipment/clothing listed below may not be required for a specific site task. Personnel should consult the SHSO for the appropriate protective equipment combination.

1. Remove tape from outer rubber gloves.

2. Remove outer gloves.

3. Remove tape from hood and respirator.

4. Remove hood back and away from face and head.

5. Remove tape from outer shoe covers.

6. Remove or cut tape from front seam of suit.

7. Remove suit back and away from body.

8. Slide pants down to ankles or roll inside out.

9. Cut pants off at ankles or roll pants inside out.

10. Dispose of suit in proper receptacle.

11. Remove tape from inner gloves.

12. Remove outer shoe cover.

13 Remove respiratory equipment

14. Remove inner glove by rolling inside out.

Personnel should familiarize themselves with this guidance and with the personnel decontamination procedures in Sect. 4.3 because these should be carried out in harmony.

\subsubsection{Respiratory protection}

Personnel at the K-1654B UCT site will be covered by a respiratory protection program that meets the requirements of 29 CFR 1910.134 and American National Standards Institute (ANSI) Z88.2 (1980) by incorporating the following conditions:

- Program administrator. 
- Standard operating procedures for selecting and using respirators.

- Proper selection of respirators on the basis of hazard.

- Training of personnel in respirator use and limitations.

- Regular cleaning and maintenance.

- Proper storage.

- Routine monthly inspections and inspections before and after use.

- Constant monitoring of work area for adverse conditions and worker stress.

- Continual evaluation of respiratory compliance program once in operation.

- Determination of medical fitness of potential user.

- Use of approved equipment only after proper fit testing has been performed. The quantitative fit test should be used to determine the user's ability to obtain a satisfactory fit with a negative pressure, air-purifying respirator. The results of the fit test will be used to select the specific type, make, size, and model of negative pressure, air-purifying respirator for use by the wearer.

The following policies should also be adhered to in the fitting and use of respirators:

1. An employee must have passed the quantitative fit test and medical evaluation to use a respirator.

2. If it is determined that an employee cannot obtain a good respirator-to-face seal because of facial or medical characteristics, that employee will neither use a respirator nor enter an atmosphere that requires the use of a respirator.

3. Facial hair such as beards, sideburns, or certain mustaches that may interfere with the fit test are not allowed.

4. Individuals requiring corrective lenses shall be provided with specially mounted lenses inside the full-face mask. Under no circumstances will contact lenses or normal glasses be worn while using full-face respirators.

5. Individuals may use only the specific make(s) and model(s) of air-purifying respirators for which they have obtained a satisfactory fit via the quantitative fit-testing procedures. Under no circumstances shall individuals be allowed to use any make or model of respirator for which they have not passed a fit test.

The determination of the potential user's medical fitness is generally based on evaluating the individual for physiological-psychological limitations as given in American National Standards Institute Standard Z88.6 (1984). Examples are

- pulmonary problems;

- cardiovascular problems;

- $\quad$ skin sensitivity, diabetes, perforated eardrum, deviated septum; and

- claustrophobia, anxiety, and discomfort. 
NOTE: The determination as to whether tank entry will be declared a confined space entry is the responsibility of the K-25 Industrial Hygiene Department upon site/work activity inspection. The K-25 Industrial Hygiene Department has determined that respirators will not be required for a confined space entry because proper engineering controls (i.e. wet methods) for lead oxide are in place. This is true only if the lead found in the K-1654B UCT is contained within a water matrix and an oxygen-deficient environment does not exist.

\subsubsection{Standard Safe Work Practices}

1. Eating, drinking, chewing gum or tobacco, smoking, and applying cosmetics are prohibited in the exclusion and contamination reduction zones, or wherever the possibility exists for the transfer of contamination.

2. Contact with potentially contaminated substances should be avoided. Do not walk through puddles, pools, mud, etc. Whenever possible, avoid kneeling, leaning, or sitting on equipment or the ground. Do not place monitoring equipment on a potentially contaminated surface (e.g., the ground).

3. Undue spillage of contaminated material should be prevented. In the unlikely event that this occurs, notify the SPM.

4. All field crew members should use their senses (all senses) to alert them to potentially harmful situations.

5. Practice good housekeeping. Keep everything orderly and out of potentially harmful situations.

6. Field crew members must be familiar with the physical characteristics of investigations, including

- wind direction in relation to ground zero;

- accessibility to associates, equipment, and vehicles;

- communications;

- hot-zones (areas of known or suspected contamination);

- site access; and

- nearest water sources.

7. The number of people and equipment in the exclusion zone should be minimized in accordance with workspace requirements for safe site operation.

8. All waste generated during the K-1654B waste removal project will be disposed of in accordance with Sect. 4.1.5 of this plan.

9. All injuries should be reported to the SHSO, no matter how minor.

10. All workers in the contamination zone will maintain verbal contact with fellow workers, or visual contact, if site conditions make hearing difficult. 
11. All individuals will make their presence known to the SPM daily, and changes in personnel will be noted. A list of workers on the job site will be maintained in the field logbook for accountability.

\subsection{PERSONNEL DECONTAMINATION PROCEDURES}

Personnel decontamination procedures are designed to eliminate/limit the spread of contaminated materials workers may encounter and to limit the spread of contamination from the exclusion zone. Decontamination procedures for levels of protective equipment C, D+, and D are included and are quite similar. The SHSO is responsible for the establishment of the exclusion, contamination reduction, and support zones. In addition, the SHSO will construct an on-site decontamination station and will instruct personnel on its proper use. Figures 4.5 and 4.6 depict minimum requirements of the decontamination stations. The following procedures will be used for personnel decontamination.

\subsubsection{Level D Protection Decontamination}

Station 1: Work area

Greatest potential for exposure to on-site contaminants.

Station 2: Segregated equipment drop

Deposit equipment used on-site (tools, sampling devices, containers, monitoring equipment, clipboards, etc.) on a plastic drop cloth or in a container with a plastic liner.

Equipment necessary: containers

plastic liners

55-gal compactible-wasie drum

Station 3: Boot, safety glasses, hard hat, and glove removal

Boots, safety glasses, hard hats, and gloves are removed. If a protective outel warment is worn to prevent soiling of field work clothes, it should also be removed at this point. Prescription safety glasses should be washed with soapy water.

Station 4: Step across line.

Enter designated support zone.

\subsubsection{Level D+ Protection Decontamination}

Level D+ protective clothing is deemed necessary when sampling operations may produce excessive splashing of surface or subsurface materials, yet the action level does not require the use of a respirator and taped, protective chemical-resistant suits. 
ORNL-DWG 91-15920

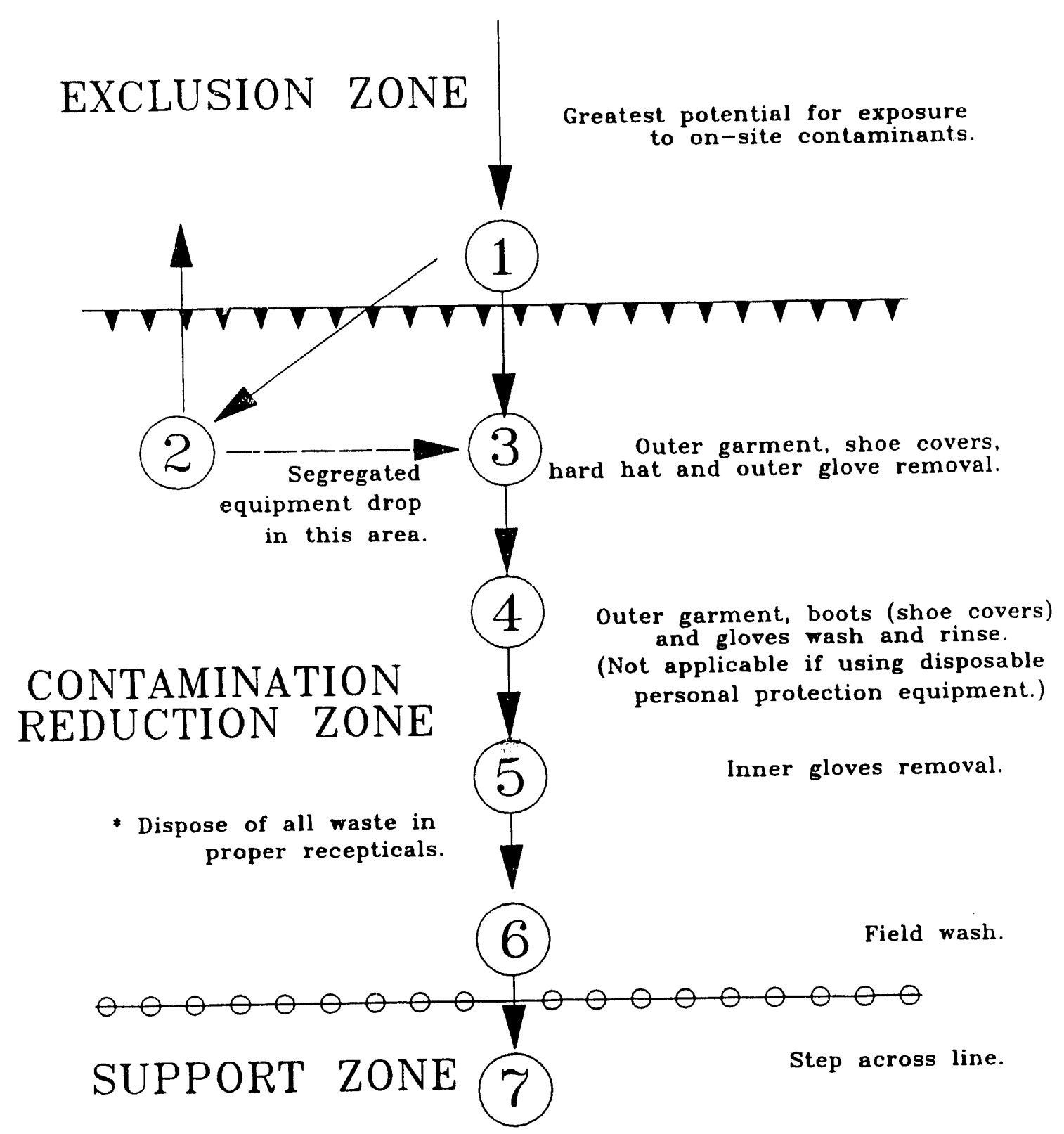

Fig. 4.5. Minimum decontamination requirements for Level D+ protection. 
ORNL-DWG 91-15921

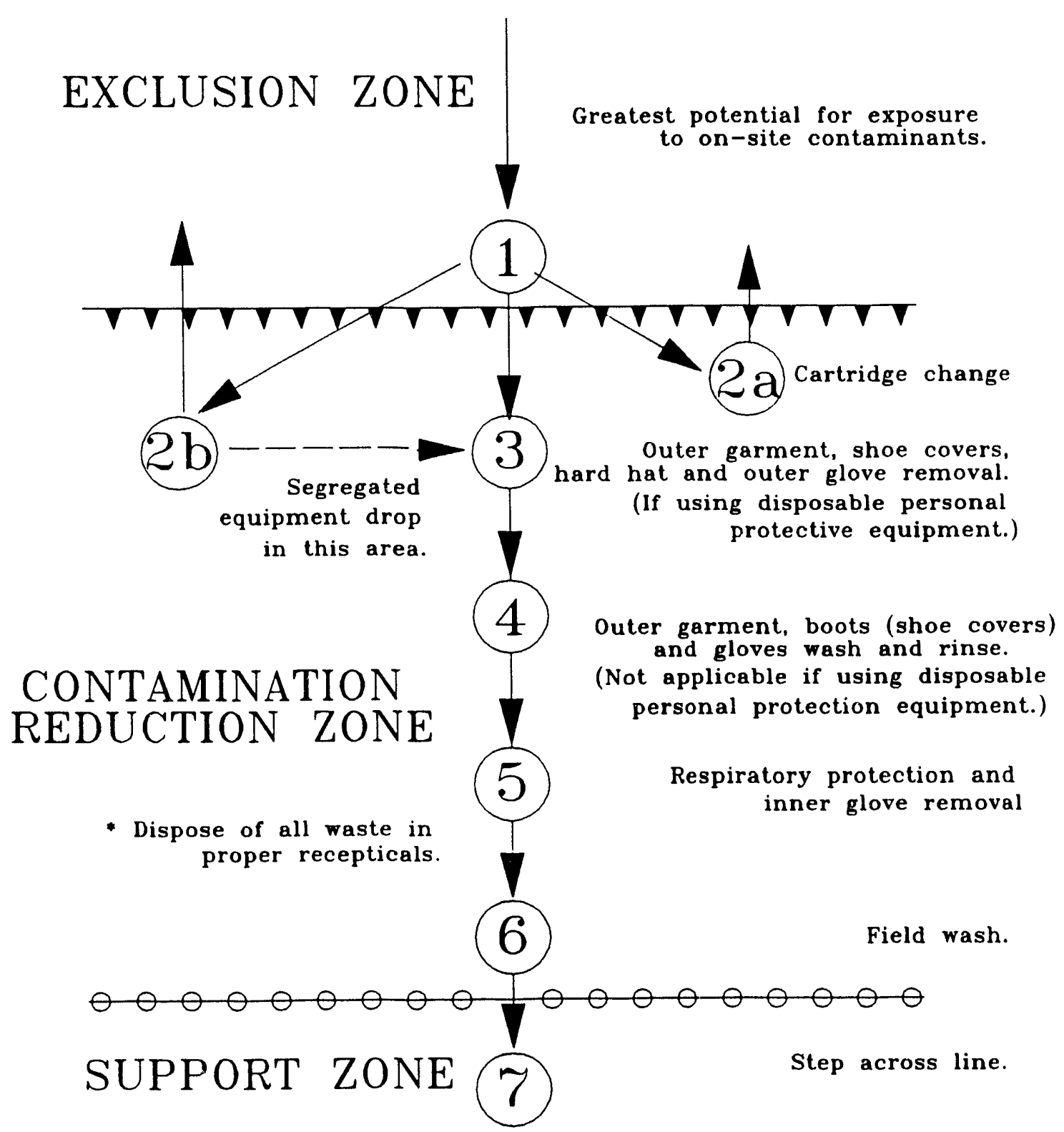

Fig. 4.6. Minimum decontamination requirements for Level $\mathrm{C}$ protection. 
Station 1: Work area

Greatest potential for exposure to on-site contaminants.

Station 2: Segregated equipment drop

Deposit equipment used on-site (tools, sampling devices, containers, monitoring equipment, clipboards, etc.) on a plastic drop cloth or in a container with a plastic liner.

\section{Equipment necessary: containers \\ plastic liners \\ 55-gal compactible-waste drum}

Station 3: Boot, safety glasses, hard hat, and glove removal

Boots, safety glasses, hard hats and gloves are removed. If a disposable protective coverall is worn, it should be removed and deposited in a lined 55-gal compactible-waste drum.

Station 4: Outer garment, boots, gloves, hard hats, safety glasses scrubbing and rinsing tools and agents.

Scrub outer boots and gloves with a laboratory-grade detergent (Liquinox or equivalent) and rinse with potable water. Clean safety glasses and hard hat in same fashion. Disposable boots and gloves need not be scrubbed and may be disposed of in the compactible-waste drums. All decontamination should take place while personnel are standing in large wash tubs if decontamination of boots is required so that all decontamination solutions can be caught and drummed in accordance with Sect. 4.1.5 of this document.

Equipment necessary: two or three wash tubs

one hand-pump sprayer

water

detergent

scrub brushes

paper towels

55-gal drum with liner for paper towels and protective clothing

Station 5: Inner gloves removal.

Inner gloves are removed.

Station 6: Field wash

Thoroughly wash hands and face. Shower as soon as possible. 
$\begin{array}{ll}\text { Equipment necessary: } & \text { water } \\ & \text { wash basin/bucket } \\ & \text { soap }\end{array}$

Station 7: Step across line.

Enter designated support zone.

\subsubsection{Level C Protection Decontamination}

Station 1: Work area

Greatest potential for exposure to on-site contaminants.

Station 2a: Canister/cartridge change

If a worker has left the exclusion zone for the sole purpose of changing a canister/cartridge of his/her respirator, this is the last step of the decontamination procedure. Once the worker's canister/cartridge has been replaced, the outer boots and gloves may be retaped so that all potential pathways to the skin are sealed. The used canister/cartridge will be placed in the plastic bag and will be disposed of in accordance with Sect. 4.1.5 of this document.

Equipment necessary: respirator cartridges/canisters

tape

extra gloves

boot covers (if worn)

plastic trash bags

Station 2b: Segregated equipment drop

Deposit equipment used on-site (tools, sampling devices, containers, monitoring instruments, clipboards, etc.) on plastic cloths or in different containers with plastic liners. Each piece of equipment will be decontaminated to a different degree, which is the reason for separating the equipment. Segregation of the equipment at the drop site reduces the possibility of cross-contamination.

Equipment necessary: various containers

plastic liners

plastic drop cloths

55-gal lined compactible-waste drum

Station 3: Outer garment, boots and glove removal

Remove outer garment, boots and outer gloves with accompanying tape. Tape and disposable gloves should be placed in a plastic trash bag and disposed of in accordance 
with Sect. 4.1.5 of this document. Reusable outer garments and boots will be placed in plastic bags for screening by the health physics department. This equipment must be scanned and green-tagged before reuse is possible. NOTE: This station is not necessary when disposable personal protective equipment is used.

Equipment necessary: plastic trash bag

bench or stool

one-hand pump sprayer

Station 4: Outer garment, boots, and gloves scrubbing and rinsing

Scrub outer garment, boots and gloves with laboratory-grade detergent and water and rinse with potable water. All wash water and rinsing solutions will be disposed of in accordance with Sect. 4.1.5 of this document. NOTE: This station is not necessary when disposable personal protective equipment is used.

$\begin{array}{ll}\text { Equipment necessary: } & \text { wash tubs } \\ & \text { water } \\ \text { detergent } \\ \text { scrub brushes }\end{array}$

Station 5: Respiratory protection and inner glove removal.

The respirator is removed next-to-last. The cartridges/canisters are placed in a plastic trash bag and disposed of in accordance with Sect. 4.1.5. The respirator is placed in a plastic bag dedicated for used respirators only. It may not be reused due to the single-use respirator policy. Respirators will be scanned and tagged by the health physics department and returned to the K-25 Industrial Hygiene Department. Remove disposable inner gloves last and deposit them in a plastic trash bag. Disposal is in accordance with Sect. 4.1.5 of this work plan/health and safety plan.

Equipment necessary: plastic trash bags

Station 6: Field wash

Wash hands and face thoroughly with soap and water.

Station 7: Step across line.

Enter designated support zone.

\subsection{EQUIPMENT DECONTAMINATION}

The equipment decontamination personnel at the K-1654B UCT may be exposed to a variety of potential hazards. Potential contaminanis of concern are outlined in Table 4.1. Decontamination personnel will be responsible for conducting possible decontamination of equipment utilized during the excavation procedures (personnel decontamination procedures 
are outlined in the previous section). Equipment decontamination will generally require level $\mathrm{D}+$ protective clothing, including eye protection. Decontamination personnel may be exposed to splash or backspray during cleaning operations; therefore, protective clothing such as Tyvek or a protective apron will be worn, in addition to a face shield mounted on a hard hat. If operations are conducted within 10-radial feet of the hot-water washer, hearing protection will also be required because of the high noise levels emitted from the engine.

\subsubsection{Discussion}

This procedure applies to all equipment that comes in contact with the surface and subsurface material, as well as the inside of the UCT, such as shovels, scoops, or any other equipment that might be involved in the actual removal process. The pump and associated tubing will be disposed of in a DOT 17C 55-gal drum.

\subsubsection{Equipment}

- Personal protective equipment (see Sect. 4.2.5)

- Potable water

- Plastic tubs or buckets

- Scrub brushes

- Wire brush

- Disposable wipes

- Laboratory detergent (such as Alconox)

- Plastic bags

- Distilled water in stainless steel sprayers

- Ultrapure isopropyl alcohol

- Hot-water washer with washing trough

- DOT 17E 55-gal drums (to containerize all wash water)

- Sheet plastic

- Aluminum foil

- Ziploc-type bags

\subsubsection{Procedure}

Equipment should be washed either in a bucket containing laboratory-grade detergent or in the decontamination trough. However, if excavation equipment is muddy, it should be rinsed with high-pressure hot water/steam prior to washing. The decontamination trough is designed to collect and drain all spoils into a containment reservoir. The wash solutions are transferred to a DOT 17E 55-gal drum. The decontamination trough is shown in Fig. 4.7. The decontamination trailer that may be used by the investigation team is shown in Fig. 4.8.

The following decontamination sequence will be used to decontaminate excavation equipment. Steps 4 and 5 in the following decontamination sequence will be performed in a dedicated containment reservoir to segregate those solutions for waste minimization purposes. 


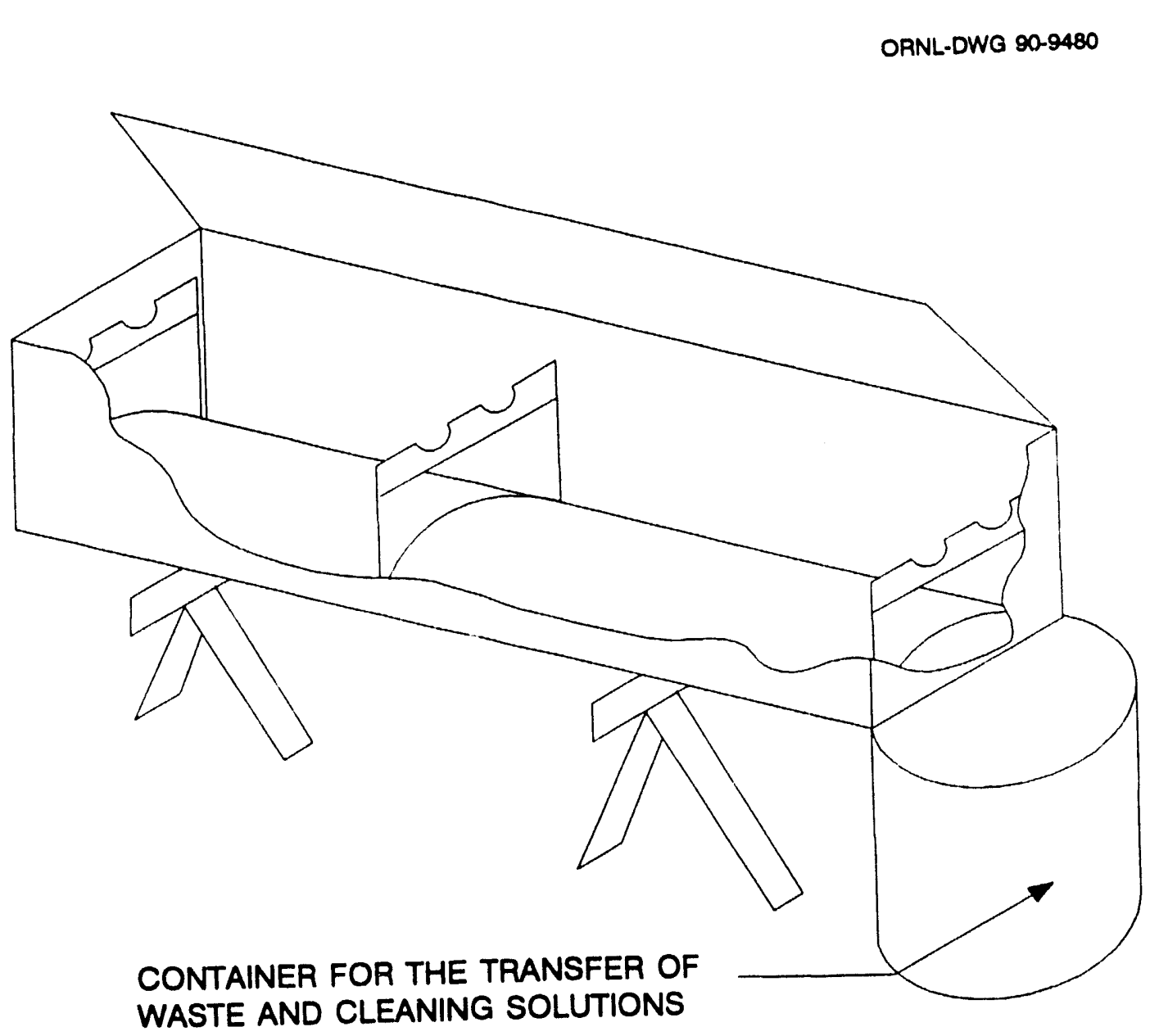

Fig. 4.7. Decontamination trough. 

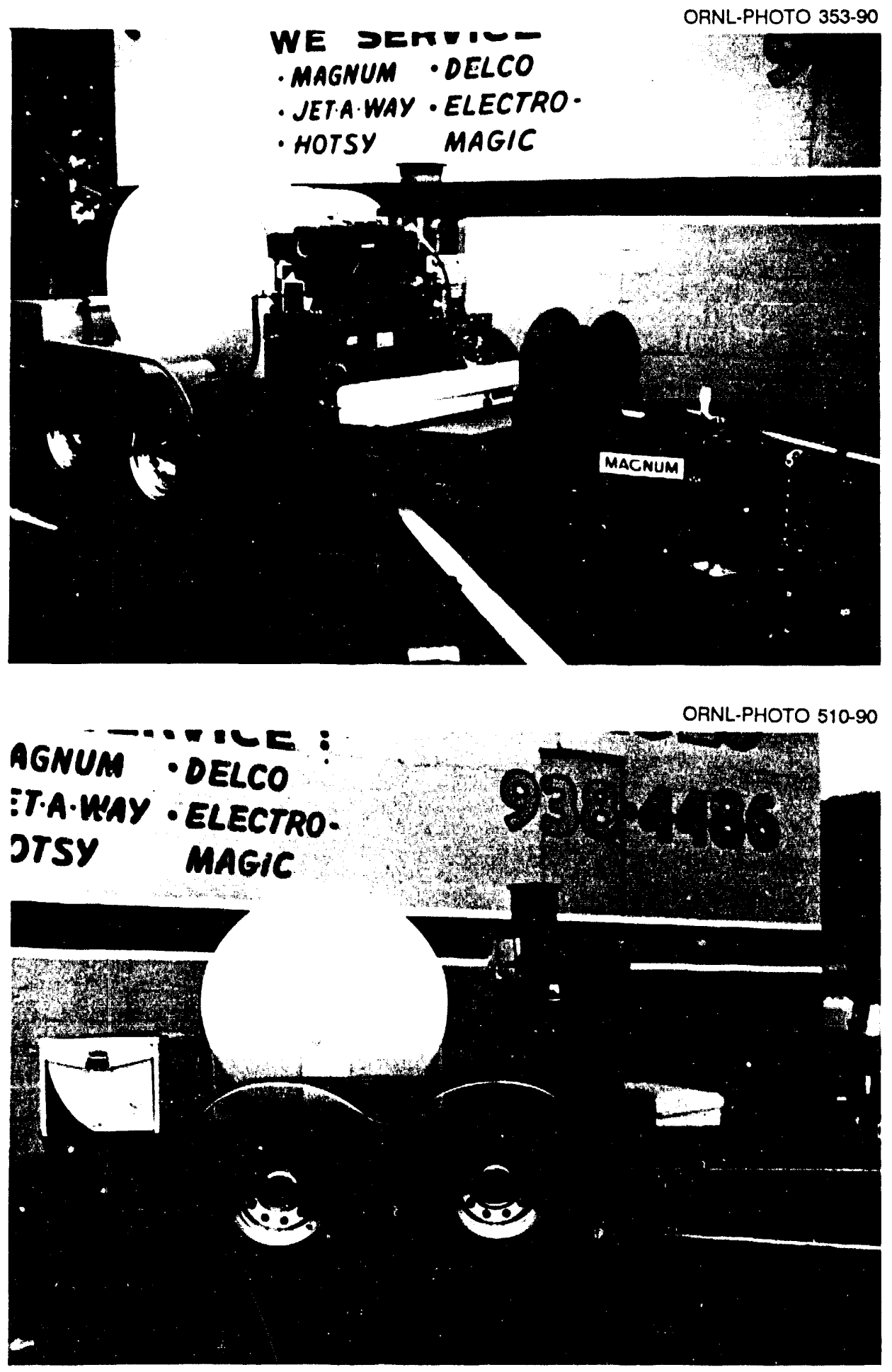

Fig. 4.8. Photographs of decontamination trailer. 
1. Wash and scrub with laboratory-grade detergent and potable water.

2. Rinse with potable water.

3. Rinse with ultrapure isopropyl alcohol

4. Rinse with deionized water.

5. Drain or capture all spoils and associated solutic ns and transfer into a DOT 17E 55-gal drum.

6. Air dry.

7. Keep in an uncontaminated area.

The liquid generated by the cleaning operation must be containerized with other decontamination waste for appropriate disposal. All decontamination should take place in a separate staging area. Cleaned equipment may be temporarily placed on a polyethylene sheet away from high-traffic areas to avoid contamination. Care must be taken in the selection of the staging decontamination area to avoid fugitive dust, fuel oils, gasoline, organic solvents, or other airborne sources of contamination. All excavation equipment must be cleaned and washed prior to use. 


\section{SAMPLING PROCEDURES, DOCUMENTATION AND CUSTODY}

The ORNL/MAD group will not be concerned with sample documentation and custody because this work plan does not require environmental sampling. 


\section{CALIBRATION PROCEDURES}

Continuous real-time assessment of potentially hazardous material concentrations will be performed on-site during the UCT removal activities. The monitoring program is designed to protect members of the team from possible hazards associated with site-specific activities.

\subsection{MONITORING PROGRAM}

Continuous real-time assessment of air quality will be performed by the SHSO while operations are being conducted in the contamination reduction zone and the exclusion zone. The deployment of monitoring equipment will depend upon the site-specific activities being conducted. Radiological monitoring equipment shall be required only at the onset of excavation because this site is historically devoid of radioactive contamination. Excavation activities require the use of specific monitoring equipment, both chemical and radiological. This monitoring program is designed to protect all on-site investigative personnel from potential chemical and radiological contaminants, within the best of our knowledge and within the limits of our resources. These contaminants are identified in Table 4.1.

\subsubsection{Instrument Calibration}

All applicable instruments shall be calibrated within the proper time frame, in accordance with the manufacturers' recommendations and specifications described in the manufacturers' standard operation procedures. Calibration readings, the lot number from the calibration gas cylinder, the calibration gas manufacturer, and each radiological source number will be recorded on the daily instrument calibration check sheet, located in the field logbook in a section dedicated to calibration and vital information about the instruments.

All chemical instrument calibration gases will be purchased from a laboratory instrumentation gas supply company. Each calibration gas cylinder must contain a manufactures label containing a lot number, manufacturer's name, type of gas, and ppm or percent of gas contained within the cylinder. All calibration gases are secondary standards.

\subsubsection{Calibration Frequency}

While in service, all instruments will be calibrated or field checked daily, or more frequently as recommended by the SHSO. More frequent calibrations and field checks may be deemed necessary if the instrument malfunctions, or the batteries are replaced or recharged, or the first calibration does not equilibrate properly. If the instrument does not meet the manufacturer's standard operation procedures after the calibration or field check, the instrument will be removed from service and replaced.

\subsubsection{Background Readings}

Before any field activities commence, background concentrations and levels near the site wil! he monitored and recorded as specified in Sects. 4 and 6 . To obtain accurate results, daily 
background readings shall take place away from areas of potential contamination. Background readings will be taken into account before an action level is established.

\subsection{CHEMICAL MONITORING}

\subsubsection{Chemical Monitoring Equipment}

Equipment necessary for environmental on-site monitoring shall consist of a four-sensor combustible gas indicator (CGI), such as a GasTech model GX86, which will be used on-site by the SHSO.

\subsubsection{Combustible Gas Indicator}

The GX86 is designed to detect potential hazards that may be posed by combustible gases, oxygen deficiency/enrichment, carbon monoxide, and hydrogen sulfide. The CGI utilized on-site should be equipped with circuitry that warrants the unit intrinsically safe, thereby allowing its operation in Class I, Division I, Group C or D hazardous atmospheres without risk of ignition.

Detection of the gases occurs by means of diffusion. The combustible gas detector is a replaceable plug-in sensor that is retained via a bayonet-type base. The sensor consists of a platinum catalyst and an electrically identical noncatalytic reference element. The noncatalytic element serves to compensate for noncombustible gases and temperature variations. The carbon monoxide and hydrogen sulfide detectors are secured by a bayonet-type fitting. The carbon monoxide detector utilizes a charcoal filter that is held in place by a rubber retaining ring. These sensors are equipped with an electrochemical cell, consisting of two precious metal electrodes in an acid electrolyte, covered with a permeable membrane composed of a fluorocarbon. The gas enters into the sensor and an electrochemical reaction produces a current that is proportional to the concentration of gas. These sensors are held in place with a bayonet-type fitting. The oxygen detector contains a sensor that consists of an electrochemical cell. The cell is composed of a gold and lead electrode in an alkaline electrolyte. The electrochemical reaction produces a current that is proportional to the percent oxygen in the environment.

\subsubsection{Chemical Monitoring Frequency}

Monitoring of $\mathrm{O}_{2}, \mathrm{CO}, \mathrm{H}_{2} \mathrm{~S}$, and combustible gases will be performed with the CGI upon entering a potentially hazardous site and at -10 -min intervals while work is being conducted in the contamination reduction zone and/or exclusion zone. All data for each monitoring occurrence will be recorded. A sample air quality monitoring record is shown in Fig. 6.1.

\subsubsection{Chemical Monitoring Equipment Action Limits}

The GX86 is equipped with a microprocessing unit that enables continuous monitoring of the four parameters simultaneously. In addition, the unit has alarms preset for the following parameters: 
AIR QUALITY MONITORING RECORD

\begin{tabular}{|l|l|l|}
\hline \hline Site & Date & Sample location \\
\hline Start On-site time: & $\begin{array}{l}\text { Measurements } \\
\text { Laken by }\end{array}$ \\
\hline Instrument & Last callbration \\
\hline Amblent weather conditions (l.e., tog. rain) & \\
\hline
\end{tabular}

CGI MEASUREMENTS

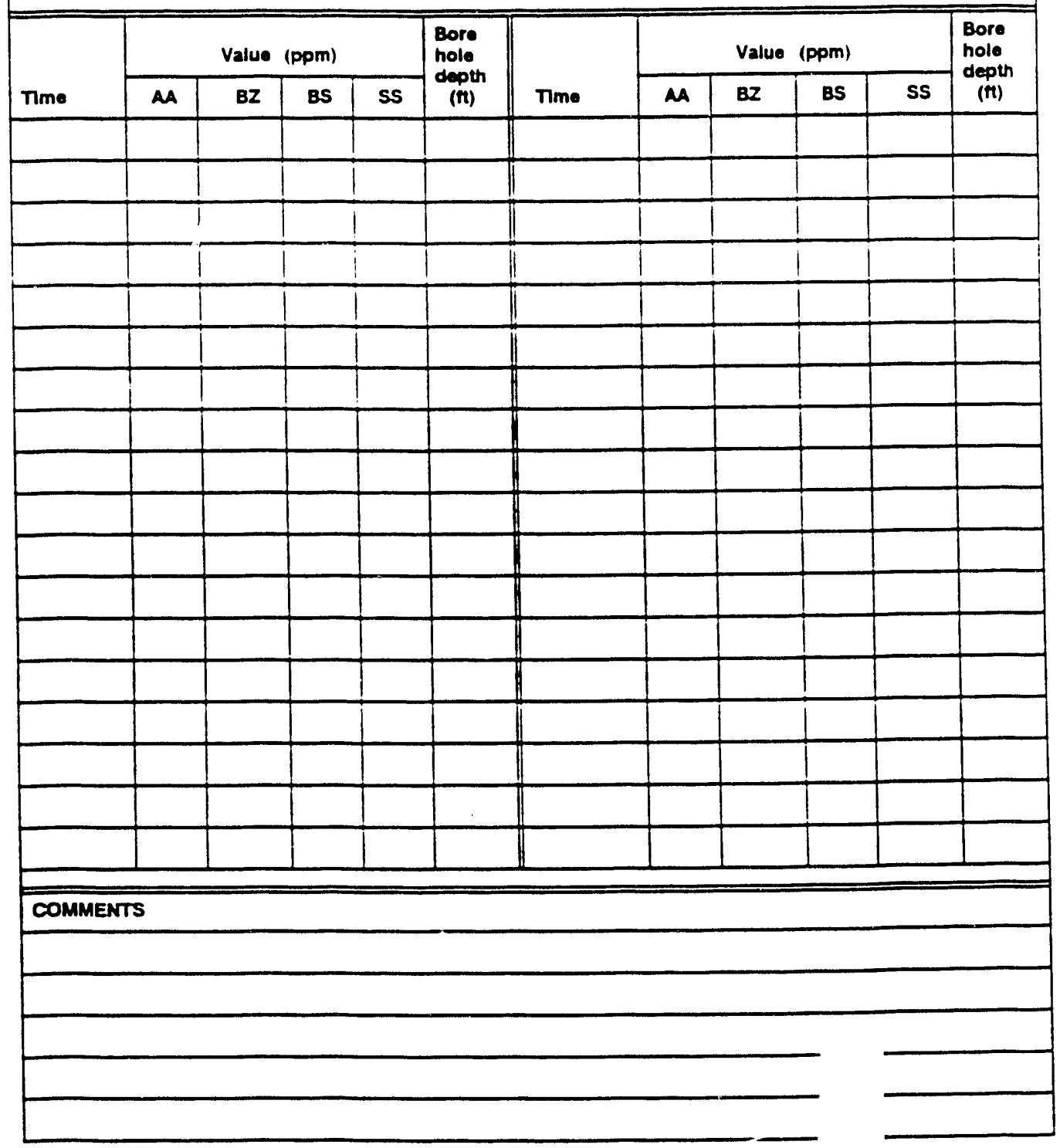

M . Amblent alr; BZ = Breathing zone; BS - Borchole epace; SS - Soll 8 $X$ Indleates background.

UCN-17034 (3 4/90)

Fig. 6.1. Air quality monitoring record. 


$\begin{array}{lll}\text { Parameter } & \text { Low Alarm } & \text { High Alarm } \\ \text { Combustibles } & 10 \% \text { of LEL } & 50 \% \text { of LEL } \\ \mathrm{O}_{2} & 19.5 \% & 22 \% \\ \mathrm{H}_{2} \mathrm{~S} & 10 \mathrm{ppm} & 30 \mathrm{ppm} \\ \mathrm{CO} & 35 \mathrm{ppm} & 100 \mathrm{ppm}\end{array}$

The tone emitted when a preset alarm level is reached is an intermittent pulse with the low alarm and a continuous tone for the high alarms. Action levels for the GX86 follow:

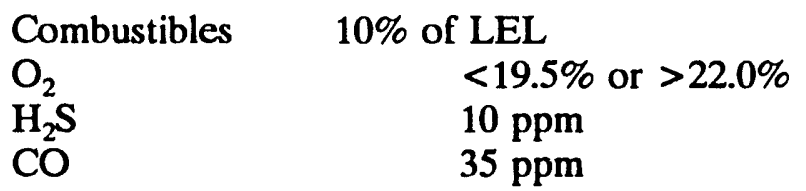

If the action limits on the GX86 are met or exceeded for more than $30 \mathrm{~s}$ in the breathing zone, all personnel, at the direction of the SHSO, should evacuate the work site upwind and to the border of the contamination reduction zone and the support zone. If not already present, an industrial hygienist representing K-25 will be summoned to the site to assess the potential hazard of the conditions and to determine whether work should continue. It may become necessary to abandon the monitoring location and proceed to the next monitoring location.

\subsection{RADIOLOGICAL MONITORING}

\subsubsection{Radiological Monitoring Equipment}

The initial radiological walkover and site monitoring at the K-1654B 500-gal UCT will be the responsibility of ORNL/MAD. These sections dealing with radiological instrumentation and monitoring present procedures followed by the MAD group, which may not coincide with those procedures followed by the K-25 Health Physics Department. The K-25 Health Physics Department will be available for consultation about any radiological concerns, if needed.

All radiological monitoring equipment used in the field is required to have up-to-date calibration stickers. No instrument that is out of calibration will be used. Instruments are maintained on an annual calibration schedule. All instruments are calibrated in accordance with NIST standards and procedures. It is also necessary to note that instrument and probe combinations are calibrated as a set, therefore, ratemeters and probes shall not be interchanged. If an instrument malfunctions, it shall be returned to the ORNL/MAD instrument technician for repair and recalibration. Instrument response check measures performed in the field are not a substitute for calibration. 


\subsubsection{NaI Scintillation Detector Source Check Procedures}

The NaI scintillator will be used to conduct the on-site walkover. Each scintillation detector requires a daily radiation source check to be performed prior to use in the field. A source check validation label is affixed to each instrument. Information on the label details a source number and the maximum and minimum acceptable responses that should be obtained when the instrument is checked with the indicated source. If the detector does not respond within the indicated range, the instrument must be removed from service and returned to the ORNL/MAD instrument technician. If the indicated source is unavailable, a correction factor for the desired source to be used may be obtained from the ORNL/MAD instrument technician. If the correction factor for this source is known, the instrument response to the source may be correlated with the response ranges listed on the instrument source check validation label. Source check response procedures follow:

1. Turn the scintillator on and record the condition of the battery in the logbook.

2. Record the instrument number and the source number in the logbook.

3. Turn the selector switch to the X10 setting; record in the logbook the background in $\mathrm{cpm}$ and the location where the reading was obtained.

4. Turn the selector switch to the $\mathrm{X} 100$ setting.

5. Place the source against the detector portion of the probe, with the long axis of the source parallel to the long axis of the probe. Place the narrow edge of the source against the probe.

6. Rotate the source around the surface of the probe and record the highest response in cpm in the logbook.

7. Confirm that the reading is within the acceptable range denoted on the source check validation label affixed to the side of the instrument. If it is not, return the instrument to the ORNL/MAD instrument technician.

8. If the instrument is not to be used immediately, turn it off to conserve the batteries.

9. If the instrument appears to respond abnormally during the course of its intended use, the preceding source check procedure should be repeated to ascertain whether the instrument is functioning properly.

10. Store the source in an approved storage location.

\subsubsection{Radiological Frequency and Action Limits}

Radiological scanning for surface gamma radiation will be performed at the K-1654B site prior to the commencement of excavation activities only. Evacuation will be required when the action level has been reached at a count rate of $800,000 \mathrm{cpm}$ at $1 \mathrm{ft}$ above the ground 
surface, measured with the NaI scintillator. Should such action levels be indicated, all personnel will move from the work site to the contamination reduction zone. A health physicist will assess the potential hazard and determine whether work should continue. The K-25 Health Physics Department will be responsible for any necessary posting of contaminated areas identified during the site investigation and field work. 


\section{ANALYTICAL PROCEDURES}

Because no sampling will be conducted in conjunction with this work plan, this area will not be addressed. 


\section{DATA MANAGEMENT PROCEDURES}

All field measurement data collected at the K-1654B UCT site is Level A and therefore not subject to a formal validation process. This data will be reviewed and maintained by the ORNL/MAD group. Copies of measurement data will be made available to the K-25 Industrial Hygiene Department as well and CTF, if needed.

Field measurement data collected during the project will be recorded or documented in the site-specific UCT field logbook and the air quality monitoring record (Fig. 6.1). This data will be recorded periodically (approximately every $10 \mathrm{~min}$ ) while operations are being conducted in the contamination reduction zone and/or the exclusion zone. Field parameters measured will include oxygen, carbon monoxide, hydrogen sulfide, and combustibles. Data from the radiological walkover will also be recorded. 


\section{INTERNAL QUALITY CONTROL REQUIREMENTS}

Because no sampling will be conducted in conjunction with this work plan, this area will not be addressed. 


\section{PERFORMANCE AND SYSTEM AUDITS}

Audits shall be made of field activities performed by Energy System personnel and subcontractors. Audits are required to ensure the quality of the work being performed. Audit preparation will include review of pertinent background information, procedures, and technical documents to acquaint the auditing team with the activity in question. A review of past records will assist auditors in recognizing previous problems and learning what types of corrective action were used in such situations.

The role of audits in the overall management program is verification. Although audits do not improve data quality, if all work is correctly performed, they do provide assurance that the work prescribed for the nieasurement program has been conducted properly.

Audits are very important to the quality control (QC) program. They provide a documented means of detecting missing $Q C$ requirements and potential problem areas. Audits form one of the bases for corrective action requirements and constitute a permanent record of the conformance of measurement systems to QA requirements.

Two types of audits will be used to monitor and document conformance with the QAPjP: performance and system audits. Performance audits are made to quantitatively evaluate the quality of data produced by the total measurement system. To obtain an independent assessment, the individuals performing the audit, their standards, and equipment must differ from the regular team that operates the measurement system. Performance audits provide objective assessments of the accuracy of the data collected by a given measurement system. They also provide identification of out-of-control measurements and systematic bias. Measurement of improvement in data quality can be obtained by comparing data from previous and current audits. System audits are qualitative on-site inspections and reviews of the total measurement system. The auditor should have extensive background experience with the measurement system being audited.

\subsection{AUDIT RECORDS}

Audit records include reports, responses to checklists and corrective actions taken. These records shall be properly documented as a QA record. The ORNL/MAD QA officer will evaluate findings of the audit reports along with the results of surveillance reports and any deficiency reports.

\subsection{FIELD AUDITS}

Field audits, or more appropriately, field surveillance, will involve short duration monitoring or the observance of an item or activity, generally by a qualified person designated as a QA surveillant. The ORNL/MAD QA officer or his/her designated QA surveillant will conduct surveillance of the on-going field activities. Surveillance, as contrasted with audits, grants wide latitude to the surveillant during the course of the surveillance. The qualified person wouid need 
- appropriate technical expertise in the area being surveilled;

- access to pertinent references, procedures, drawings, specifications, etc.;

- access to the area where surveillance is to be conducted; and

- not to be directly involved in the performance of the activities surveilled.

Typical surveillance activities include

- performing a general review of procedures, instructions, and associated documents applicable to the project, and

- observing ongoing work activities and associated quality assurance activities to verify that these work activities are being performed in accordance with project documentation.

The results of the surveillance will be discussed with the person(s) who performed the work activity. These results are documented and signed by the surveillant. The field audits and surveillance reports generated by the ORNL/MAD QA officer or his/her designated surveillant will be maintained on file by the MAD QA officer with copies going to the SPM and $M A D$ group leader. All reports and audits by any other surveillance organization will be the property of that organization and maintained by the same. 


\section{PREVENTIVE MAINTENANCE}

In this section, preventive maintenance procedures are described for field monitoring instruments, and radiological equipment.

\subsection{FIELD SAMPLING INSTRUMENTS}

To ensure compliance of all field sampling instruments and to minimize instrument malfunctions and/or failure, the ORNL/MAD group implements a preventive maintenance program for group-owned instruments. All ORNL/MAD chemical instruments are sent annually for maintenance and recalibration. Chemical instruments whose annual calibration is overdue shall not be used in the field until they have been calibrated.

A data base is employed by the ORNL/MAD instrument technicians, both radiological and chemical, to track maintenance histories as well as calibration dates for each instrument maintained by the group. When an instrument is returned to the instrument technicians, due to failure or expiration of the instrument's calibration, the technicians will record the instrument in the data base. The technicians will then repair the instrument or return it to its specific calibration facility. Upon receiving the instrument from the calibration facility, a new calibration sticker will be affixed to the side of the instrument and returned to the field for use. The date and corrective action taken at the calibration facility will be entered in the data base for future reference.

A daily calibration, or instrument response check, is performed (see Sect. 6) on each instrument before it is used in the field. Instruments that do not meet factory standards for any reason are removed from service. The instruments' removal is documented in the field logbook, and the instrument is returned to the ORNL/MAD laboratory for maintenance. If the ORNL/MAD instrument technician cannot effect repairs, the instrument is returned to the manufacturer or ORNL repair facility (ORNL Instrumentation and Controls Division).

Instruments belonging to the K-25 Industrial Hygiene Department are maintained and calibrated through that department's preventive maintenance program, which ensures the reliability and compliance of their own equipment. Instrumentation used by the K-25 Industrial Hygiene Department usually differs from instrumentation employed by ORNL/MAD; therefore, each group utilizes and is responsible for its own instrumentation procedures.

The nature and intended use of instruments in the field require anticipation of potential problems. In order to minimize downtime due to instrument failure, whenever possible, backup instruments will be calibrated and maintained in the support zone (see Sect. 4). 


\subsection{RADIOLOGICAL INSTRUMENTS}

All radiological instruments owned by the MAD group are maintained and calibrated by the ORNL/MAD instrument technician, ORNL Instrumentation and Controls/Office of Environmental and Health Protection, and/or private contracting facilities in accordance with manufacturers' specifications and National Institute of Science and Technology (NIST) Standards. Each instrument is then given a valid calibration certificate before it is taken into the field. Response check requirements for each instrument and additional requirements for radiological field screening instrumentation may be found in Sect. 6.

Radiological Field Screening Equipment:

Check sources

Several backup instruments

\subsection{CHEMICAL DETECTION INSTRUMENTS}

All chemical detection instruments are maintained and calibrated by ORNLIMAD in accordance with their manufacturers' standard operating procedures. Parts may be replaced and/or repaired without returning the instrument directly to the factory; therefore, whenever possible, maintaining critical replacement parts is a value measure to insure continued sampling time.

Preventive maintenance for all instruments is performed in accordance with the manufacturers' standard operating procedures. An example of a preventive maintenance schedule and a listing of critical replacement parts for the instrument used at the K-16,4B UCT site is listed below.

Combustible gas indicator (CGI): Preventive maintenance on the CGI should be performed weekly while the instrument is in use or as needed when not in service. This maintenance consists of a general cleaning of the instrument, replacement of batteries, carbon monoxide sensor filter change, and sensor changes if needed.

Critical parts list for CGI:

Replacement sensors

Replacement batteries

Confined space entry kit

Calibration equipment 


\section{PROCEDURES USED TO ASSESS DATA PRECISION, ACCURACY, AND COMPLETENESS}

The processing of QC sample results will not be addressed in this plan because no sampling will be conducted for this site activity. In addition, all field measurement data collected at the K-1654B UCT site meet Level A criteria and are therefore nonquantitative in nature and used only as indicator parameters. Equipment capability or the anaiytical QC implemented will limit data obtained to qualitative or, at best, semiquantitative. Thus, Level $\mathrm{A}$

measurement data will be used in this document only for the following: (1) delineation of contaminated zones and (2) health and safety screening.

Field measurement instrumentation detection limits and precision are presented in Table 3.1. 


\section{CORRECTIVE ACTION}

Conditions adverse to quality, which may affect safety, health, and the environment, or the reliability of activities and/or data, must be promptly identified and corrected by authorized personnel. The root cause of these significant conditions also must be properly documented and reported to management in a timely manner.

Conditions adverse to quality are defined as conditions that exceed predetermined acceptability limits, deviate from prescribed methods, fail to meet performance requirements or data quality objectives, or fail to meet customer or regulatory requirements and expectations. Typical reasons for corrective action include: nonconformances; occurrences; management reviews; appraisals, audits, problem investigations; and external appraisals, reviews, and audits.

\subsection{PROCEDURE}

Project personnel shall use the following corrective action procedure when conditions are adverse to quality:

1. The person who detects the adverse condition shall immediately provide the field, laboratory, or other appropriate supervisor with the time, date, location, and personnel involved, and a description of the adverse conditions.

2. The supervisor or SHSO shall immediately determine if wurk should be stopped and/or if a short term fix is needed. The K-25 PPS's office should be consulted to determine whether the conditions must be entered into the Occurrence Reporting System.

3. The SPM or SHSO shall notify the project manager (Tom McCoig, 574-1537; J. L. Davis, 574-6069) of the conditions. If a predetermined action limit is reached in the field, the SHSO shall ensure that the appropriate support organization (health physics department or industrial hygiene department) is consulted immediately to provide further direction before field operations may continue.

4. The project manager (Tom McCoig, 574-1537; J. L. Davis, 574-6069) shall notify the program manager (Lee Barnes, 574-3220) of the conditions and assemble a team to perform root cause analysis and determine corrective action.

5. Prior to implementing the corrective action, the ORNL/MAD QA officer, with technical assistance as needed, shall verify that the proposed corrective action will prevent recurrence of the conditions.

6. The ORNL/MAD QA officer shall verify that the corrective action is properly implemented. 
7. The project manager (Tom McCoig, 574-1537; J. L. Davis, 574-6069) shall be responsible for ensuring that corrective action documentation is completed.

8. The SPM and SHSO shall be informed immediately of any field conditions that may adversely affect the immediate health and safety of site personnel.

\subsection{OCCURRENCE REPORTING}

As of August 30,1990, the implementation of Department of Energy (DOE) Order 5000.3A, Occurrence Reporting and Processing of Operations Information, became effective. The occurrence reporting system (ORS) procedure may be initiated if an employee, contractor, or subcontractor reports problems, concerns, conditions, adverse conditions or events that could affect safety, the environment, health, quality, security, or the PPS. In some cases, the PPS may notify K-25 Security of an occurrence. If the event involves a real-time occurrence that required assistance from plant emergency services, site investigation personnel should first take action to mitigate the occurrence (see Sect. 2.7). The line manager to contact in the case of a reportable occurrence at the CTF site is Lee Barnes at 574-3220. NOTE: ORNL/MAD personnel will also be required to follow the ORNL occurrence reporting procedures and to notify the HASRD line manager, Dick Swaja at 576-5212.

Any deviation from the work plan or change in analytical procedure must be reported and recorded in the field logbook when it occurs. A photocopy of that logbook entry will be distributed to all involved parties after the occurrence has been addressed and rectified. In the event of a deviation in sampling or any field procedure, a report will be completed, approved, and circulated to all involved parties. Any major changes that will alter analytical results or that detours drastically from any aspect of this plan will require prior approval from the individuals who approved the original document. Changes in laboratory analytical technique and upgrading of health and safety protection are examples of changes that will require prior approval. 


\section{QUALITY ASSURANCE REPORTS TO MANAGEMENT}

The SPM and SHSO will refer to this document if any questions arise during the UCT waste removal process. Any deviations, deletions or additions to any phase of this project will be documented in the field logbook.

QA activities are reported to the ORNL/MAD group leader by means of internal correspondence. Short-term quality deficiencies addressed at the work site are documented in the field logbook. All QA reports will be maintained and kept on file at ORNL/MAD. The $\mathrm{MAD} / \mathrm{QA}$ representative will be responsible for maintaining files. 


\section{REFERENCES}

American Conference of Governmental Industrial Hygienists (ACGIH), 1991-1992 Threshold Limit Values for Chemical Substances and Physical Agents and Biological Exposure Indices, ISBN: 0-936712-92-9, ACGIH, Cincinnati, OH, 1991.

Environmental Protection Agency (EPA), Interim Guidelines and Specifications for Preparing Quality Assurance Project Plans, QAMS-005/80, EPA-600/4-83-004, NTIS PB-83170514, Office of Monitoring Systems and Quality Assurance, Office of Research and Development, Environmental Protection Agency, Washington, DC, December 1980.

Guidance for Conducting Remedial Investigations and Feasibility Studies Under CERCLA, EPA/540/G-89/004, OSWER Directive 9355.3-01, Office of Emergency Remedial Response, U.S. Environmental Protection Agency, Washington, DC, October 1988.

National Institute for Occupational Safety and Health (NIOSH), NIOSH Pocket Guide to Chemical Hazards, DHHS(NIOSH) Publication No. 90 :17, NIOSH, Cincinnati, OH, June 1990.

Oak Ridge Gaseous Diffusion Plant (ORGDP), Construction Environmental, Safety, Health, and Security Handbook, K/RA-101, Martin Marietta Energy Systems, Inc., ORGDP, May 1988.

Occupational Safety and Health Administration, Standards for Hazardous Waste Operations and Emergency Response (29 CFR 1910.120), March 1989. 


\section{DISTRIBUTION}

1. S. L. Barnes

2. D. E. Bohrman

3. S. N. Burman

4. J. L. Davis

5. J. L. Haymore

6. R. K. Holmes

7. S. V. Kaye

8. D. C. Landguth

9. L. K. Ledford

10. R. A. Mathis

11. T. M. McCoig

12. R. W. Oliver
13-15. M. S. Panter

16. R. W. Ray

17. C. J. Satterwhite, Jr.

18. A. W. Saulsbury

19. R. E. Swaja

20-22. M. S. Uziel

23-28. MAD Records Center

29-31. Laboratory Records--RC

32. Central Research Library

33. ORNL Technical Library, Y-12

34. ORNL Patent Section

35. Office of Assistant Manager for Energy Research and Development, Department of Energy Field Office, Oak Ridge, P.O. Box 2001, Oak Ridge, TN 37831-8600

36. C. B. Hamilton, The University of Tennessee, 1914 Andy Holt Ave., Knoxville, TN 37996-2700.

37-48. Office of Scientific and Technical Information, P.O. Box 62, Oak Ridge, TN 37831 

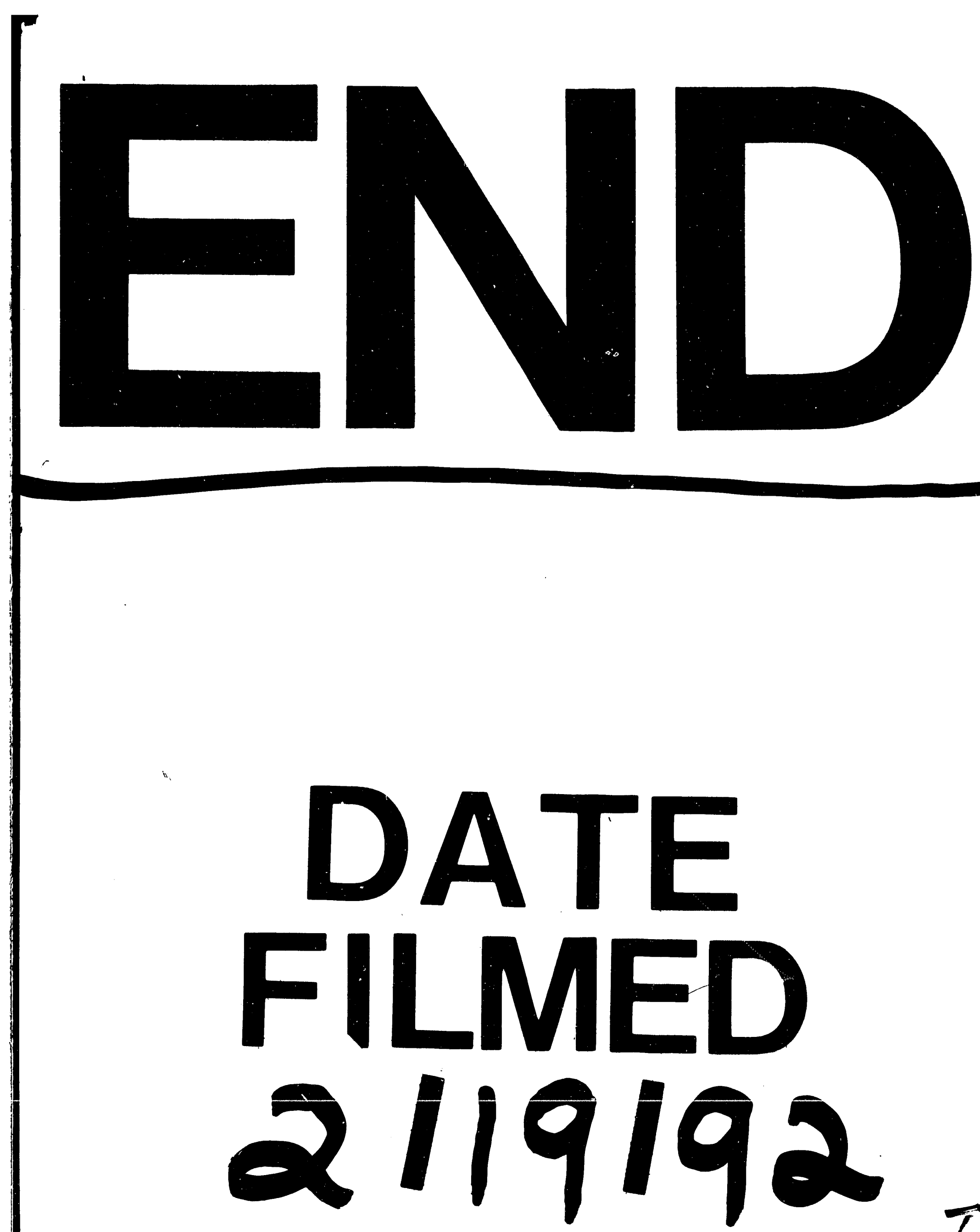

$I$ 


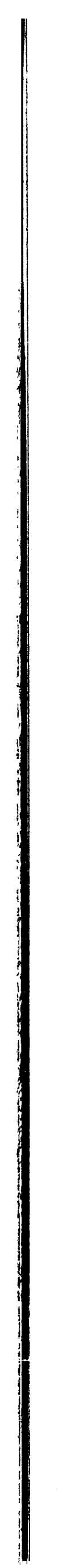

